\title{
Former dynamic behaviour of a cold-based valley glacier on Svalbard revealed by basal ice and structural glaciology investigations
}

\author{
Harold LOVELL, ${ }^{1,3^{*}}$ Edward J. FLEMING, ${ }^{2,3}$ Douglas I. BENN, ${ }^{3,4}$ Bryn HUBBARD, ${ }^{5}$ \\ Sven LUKAS, ${ }^{1}$ Kathrin NAEGELI ${ }^{3,6}$
}

\author{
${ }^{1}$ School of Geography, Queen Mary University of London, London, UK \\ ${ }^{2}$ School of Geography, Earth and Environmental Sciences, University of Birmingham, Birmingham, UK \\ ${ }^{3}$ Department of Geology, University Centre in Svalbard (UNIS), Longyearbyen, Norway \\ ${ }^{4}$ School of Geography and Geosciences, University of St Andrews, St Andrews, UK \\ ${ }^{5}$ Institute of Geography and Earth Sciences, Aberystwyth University, Aberystwyth, UK \\ ${ }^{6}$ Department of Geosciences, University of Fribourg, Fribourg, Switzerland \\ Correspondence: Harold Lovell <harold.lovell@port.ac.uk>
}

\begin{abstract}
Large numbers of small valley glaciers on Svalbard were thicker and more extensive during the Little Ice Age (LIA), demonstrated by prominent ice-cored moraines up to several kilometres beyond present-day margins. The majority of these glaciers have since experienced a long period of strongly negative mass balance during the 20th century and are now largely frozen to their beds, indicating they are likely to have undergone a thermal transition from a polythermal to a cold-based regime. We present evidence for such a switch by reconstructing the former flow dynamics and thermal regime of Tellbreen, a small cold-based valley glacier in central Spitsbergen, based on its basal sequence and glaciological structures. Within the basal sequence, the underlying matrix-supported diamict is interpreted as saturated subglacial traction till which has frozen at the bed, indicating that the thermal switch has resulted in a cessation of subglacial sediment deformation due to freezing of the former deforming layer. This is overlain by debris-poor dispersed facies ice, interpreted to have formed through strain-induced metamorphism of englacial ice. The sequential development of structures includes arcuate fracture traces, interpreted as shear planes formed in a compressive/transpressive stress regime; and fracture traces, interpreted as healed extensional crevasses. The formation of these sediment/ice facies and structures is indicative of dynamic, warm-based flow, most likely during the LIA when the glacier was significantly thicker.
\end{abstract}

KEYWORDS: Arctic glaciology, basal ice, ice dynamics, structural glaciology, subglacial sediments

\section{INTRODUCTION}

Valley glaciers on the High Arctic archipelago of Svalbard have typically experienced continuous recession and thinning since reaching their Neoglacial maximum positions towards the end of the Little Ice Age (LIA; AD 1900), except those that have surged during this time. This recession has largely been in response to the significant step-like increase in warming at the start of the 20th century which marked the termination of the LIA (Hanssen-Bauer and others, 1990), resulting in predominantly negative mass balances for many glaciers (Dowdeswell and others, 1997). The majority of small $(<5 \mathrm{~km}$ long) land-terminating valley glaciers are now likely to be largely or entirely cold-based and frozen to their beds, although this is unlikely to have been the case when the glaciers were substantially thicker and more extensive at their LIA maxima (e.g. Hodgkins and others, 1999; Stuart and others, 2003; Hambrey and others, 2005; Midgley and others, 2013). Thus, many glaciers are currently in the process of undergoing, or have already undergone, a switch from a polythermal to a cold-based thermal regime (e.g. Hodgkins and others, 1999; Hambrey and others, 2005). Reconstructing the timing and characteristics of these

*Present address: Department of Geography, University of Portsmouth, Portsmouth, UK. changes is important as it provides a robust link between glacier thermal regime and climate cycles, which also has implications for associated changes to flow dynamics (e.g. Hambrey and others, 2005), such as thermally controlled surge behaviour (e.g. Fowler and others, 2001), and the existence (and mobility) of subglacial microbial life (e.g. Tranter and others, 2005; Hodson and others, 2008). The difficulty lies in elucidating the exact nature of thermal regimes during the LIA, as this typically exists beyond observational and instrumented records (cf. Hambrey and others, 2005). Glacial geomorphology can be used to reconstruct the former dimensions and thickness of small valley glaciers but often provides few direct clues about past flow dynamics or thermal regime. This is because glacier forelands are typically dominated by thermo-erosion processes associated with the degradation of buried ice. These processes often negate the preservation of small-scale or poorly defined landforms that may be diagnostic of former warm-based flow (e.g. flutes) due to widespread sediment remobilization and meltwater action (Etzelmüller and others, 1996; Lukas and others, 2005; Evans, 2009).

Evidence may, however, be preserved in basal ice sequences and the internal structural attributes of a glacier, as the formation and evolution of both is often linked to dynamic, warm-based ice flow (e.g. Sharp and others, 1994; 


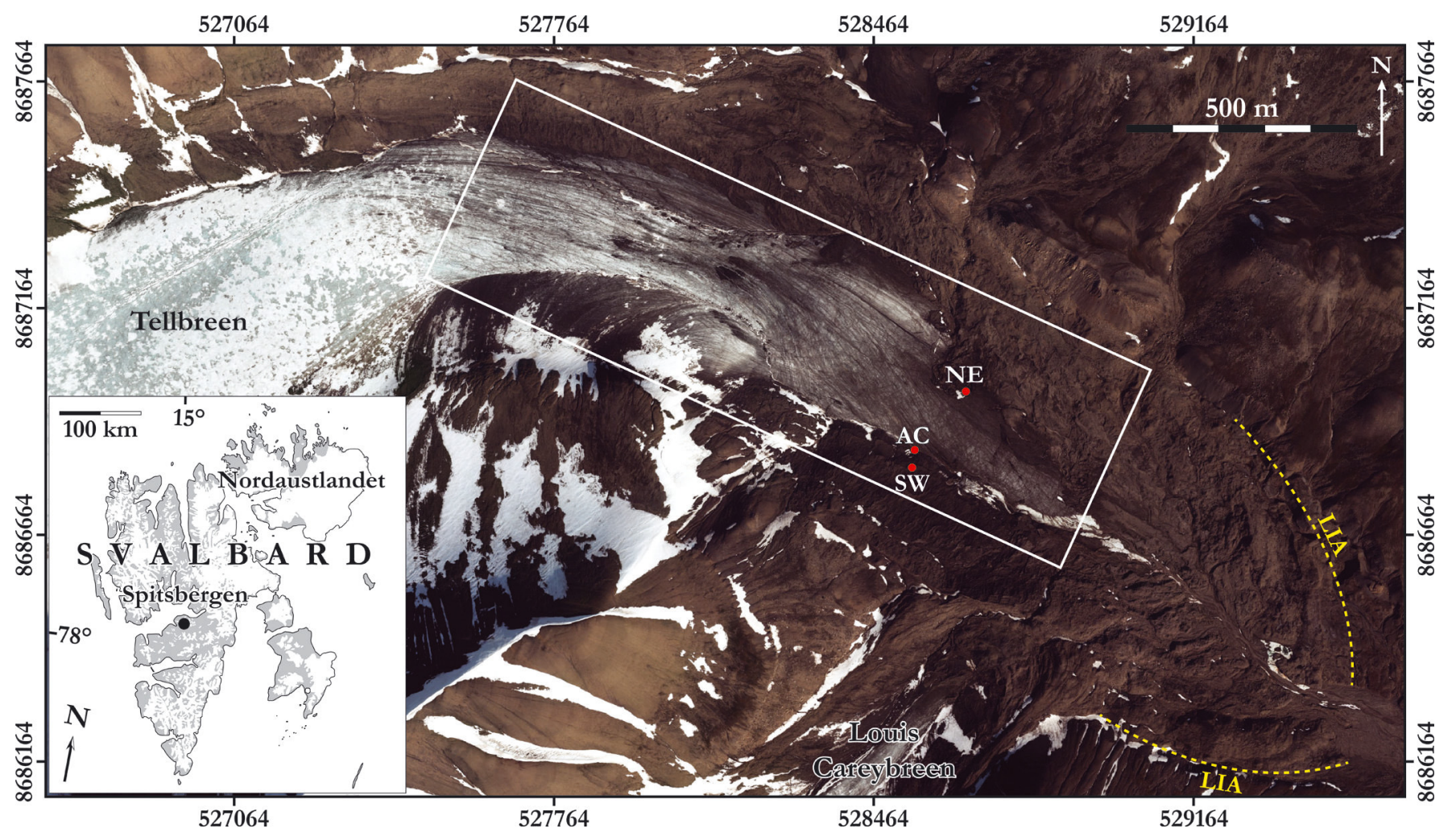

Fig. 1. Location map of Tellbreen in central Spitsbergen. The 2009 aerial photograph mosaic (S2009_1383500426 and 00428) of the glacier lower tongue and neighbouring Louis Careybreen (unofficial name) is published with the permission of Norsk Polarinstitutt (NPI). Red dots show location of SW, AC and NE cave entrances. Yellow dashed line shows LIA maximum position based on Bælum and Benn (2011). White rectangle delimits area mapped in Figure 8. Inset shows location of Tellbreen (black dot) within Svalbard.

Alley and others, 1997; Hambrey and others, 2005; Cook and others, 2011). Sharp and others (1994) assessed the physical and isotopic characteristics of basal ice exposed at the margins of Variegated Glacier, Alaska, USA. They were able to link the formation of different facies to processes active during the dynamic ice flow of a surge. These processes included freeze-on of subglacial meltwater in close association with the debris-rich bed, apron overriding (cf. Evans, 1989), tectonic thickening due to folding and faulting of units, and metamorphism of glacier ice in close proximity to the bed. It has also been demonstrated that the threedimensional (3-D) structural attributes of a glacier can be directly related to dominant strain patterns within the ice, and changing flow dynamics can be inferred from the sequential development of structures (e.g. Lawson and others, 2000; Hambrey and others, 2005). At Midtre Lovénbreen, northwest Svalbard, the analysis of structural attributes and their evolution over time allowed Hambrey and others (2005) to determine that the formation of different structural elements was dependent on spatial and temporal variations in the flow regime of the glacier, characterized by simple shear close to flow unit boundaries (longitudinal foliation), longitudinal compression (arcuate fractures, interpreted as thrusts) and extensional flow (crevasse traces). It was concluded that the structures relating to compressive and extensional flow regimes, which were no longer actively forming, were most likely to have developed during the LIA, when the glacier was thicker, warm-based and more dynamic. Investigations of basal ice sequences and the internal structure of a glacier can therefore be extremely valuable for determining past flow dynamics when direct observations or diagnostic landform-sediment assemblages are absent.

The main aims of this paper are: (1) to describe and map the basal sequence and glaciological structures exposed at Tellbreen, a small cold-based valley glacier; (2) to reconstruct the formation of sediment/ice facies and the development of structural attributes; and (3) to assess evidence for changes to the flow dynamics and thermal regime of the glacier, and to consider the implications for the relationship between dynamic instabilities and climate change.

\section{STUDY SITE AND METHODS}

Tellbreen is a $4 \mathrm{~km}$ long, $0.5 \mathrm{~km}$ wide land-terminating valley glacier in central Spitsbergen $\left(78^{\circ} 15^{\prime} \mathrm{N}, 16^{\circ} 12^{\prime} \mathrm{E}\right)$, located $\sim 12 \mathrm{~km}$ east of Longyearbyen, the main settlement on Svalbard (Fig. 1). The glacier is fed by two high-elevation accumulation basins (up to $950 \mathrm{~m}$ a.s.l.) and terminates at $\sim 300 \mathrm{~m}$ a.s.l. in a $\sim 0.5 \mathrm{~km}^{2}$ area of ice-cored moraine. Local bedrock comprises sandstones, siltstones and shales of the Van Mijenfjorden and Adventdalen Groups (Dallmann and others, 2002). Ground-penetrating radar (GPR) data indicate that Tellbreen is currently almost entirely coldbased, with possibly only a small isolated area of warm ice below the thickest ( $100 \mathrm{~m}$ ) part of the glacier (Bælum and Benn, 2011). It was suggested by Bælum and Benn (2011) that warm-based ice may have been more extensive at the LIA maximum extent of the glacier, but, based on the minimal evidence for valley erosion or modification, was unlikely to have been widespread or prolonged. Since the LIA, Tellbreen has undergone terminus retreat of $\sim 1 \mathrm{~km}$ 

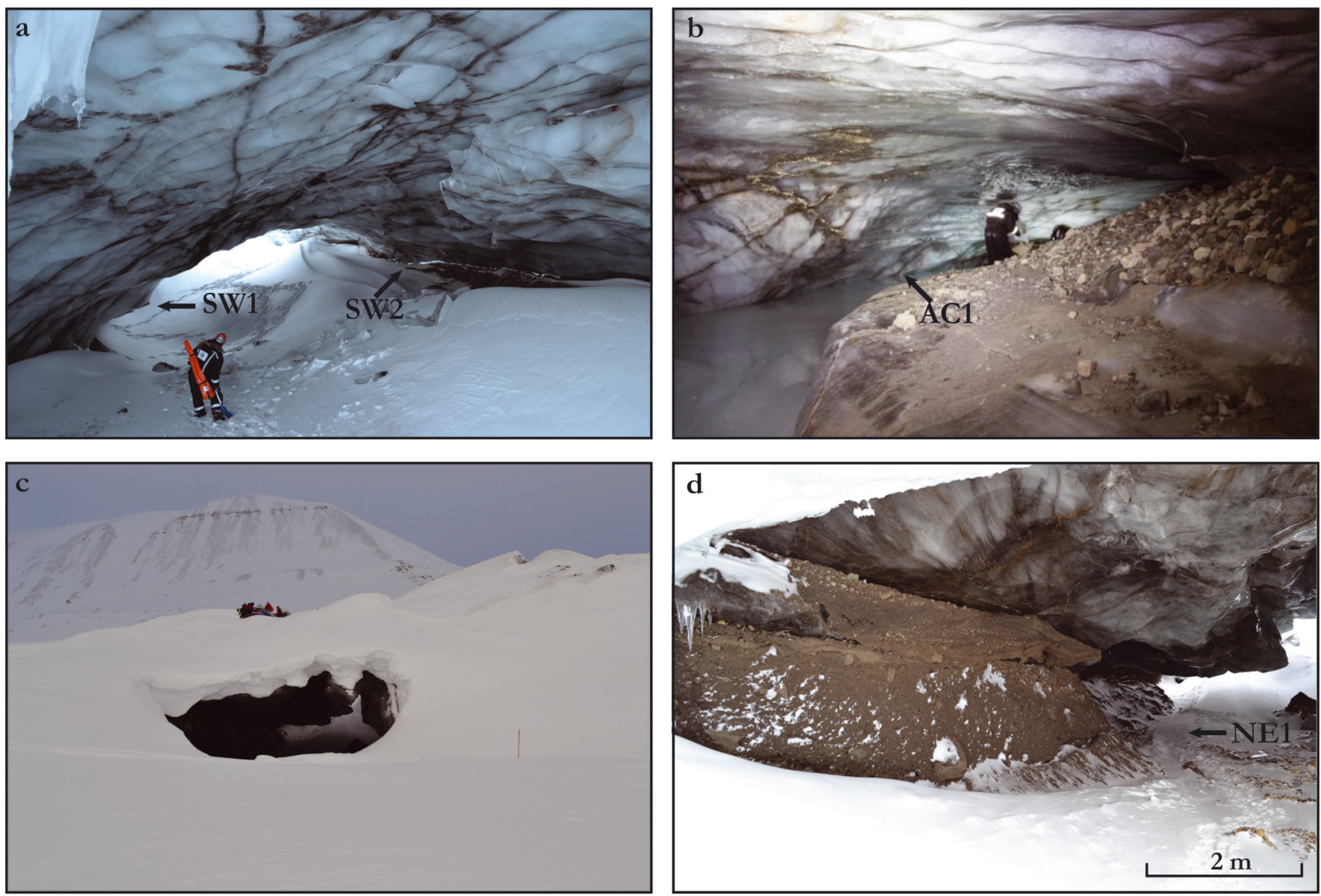

Fig. 2. Ice caves within Tellbreen lower glacier tongue. (a) SW cave with SW1 and SW2 sections arrowed. (b) AC cave with AC1 section arrowed. (c) Down-glacier entrance of NE cave. (d) Matrix-supported diamict and sand and gravel overlain by dispersed facies ice within NE1 section.

(Fig. 1) and an estimated $\sim 60-70 \%$ loss of ice volume and $>50 \%$ reduction in glacierized area. A long-term mass balance of $-0.6 \pm 0.2 \mathrm{~m}$ w.e. $\mathrm{a}^{-1}$ has been calculated over this period (Bælum and Benn, 2011), similar to the average calculated for all Svalbard glaciers $\left(-0.55 \mathrm{~m} \mathrm{a}^{-1}\right.$; Dowdeswell and others, 1997). Bælum and Benn (2011) found no evidence to suggest Tellbreen had ever undergone surge behaviour.

Tellbreen has an active drainage system characterized by a network of supra-, en- and subglacial conduits formed by cut-and-closure processes (incision followed by roof closure), which even within a cold glacier can route meltwater from the surface to the bed (Bælum and Benn, 2011; Naegeli and others, 2014). For the purposes of this study, the presence of active and abandoned conduits within the lower glacier tongue provided an accessible way to investigate ice facies and glaciological structures when they were largely free of water during spring.

Three conduits, or caves, were investigated, named the southwest (SW), active conduit (AC) and northeast (NE) caves (Figs 1 and 2). The SW cave (Fig. 2a) is an abandoned conduit located close to the indistinct transition between ice-cored moraine and debris-covered glacier; the AC cave (Fig. 2b; 'Crack cave' in Naegeli and others, 2014) is the lowermost englacial section of a conduit that emerges from the glacier front at the cave entrance; and the NE cave (Fig. 2c) is an open, cavern-like area formed by meltout of the former northeast lateral channel ('Feather cave' in Naegeli and others, 2014). The AC and NE caves gave access to the glacier bed, while the SW cave is located $\sim 5 \mathrm{~m}$ above the bed. The distributions of sediment and ice facies and glaciological structures were logged as two-dimensional (2-D) sections across the three caves, named the SW1, SW2, AC1 and NE1 sections (Figs 2 and 3). In places, the exposures of glacier ice are coated by thin layers of refrozen meltwater, which are shown where relevant but are not described in any detail in this paper.

Sediment and ice facies were identified and classified according to their physical characteristics following Evans and Benn (2004) and Hubbard and others (2009), respectively, including overall facies thickness, structure, debris content and bubble content (Table 1). A combination of both the sedimentological (Evans and Benn, 2004) and basal ice facies (Hubbard and others, 2009) classification schemes was necessary in order to fully capture the variation in sediment and ice facies present within the caves, particularly in relation to areas comprising debris-rich ice/ice-rich debris. Decimetre-scale blocks were removed with an ice axe and sampled for debris concentration, grain-size distribution and stable isotope analysis. Debris concentrations (\% by volume) were calculated by melting the sample in a beaker, allowing the debris to settle and recording the total volume and volume of the debris, following Knight (1997) and Waller (1997). Similar to Waller (1997), a value of $<1 \%$ was recorded for samples with a debris concentration too low to measure. Grain-size distributions of the debris were determined by dry sieving $(-4.0$ to $1.0 \phi)$ and laser granulometry $(<1.0 \phi)$ and plotted using GRADISTAT (Blott 


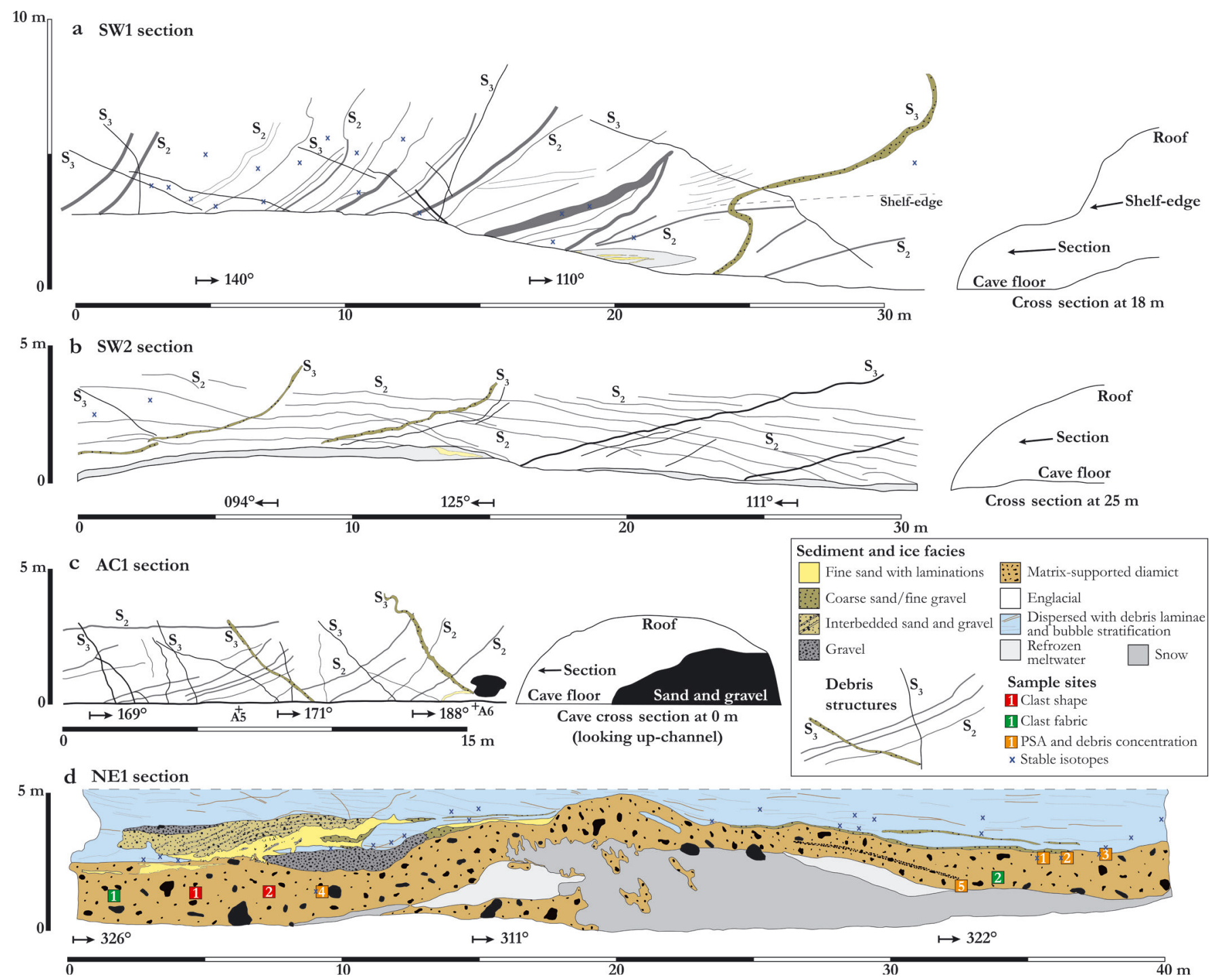

Fig. 3. Two-dimensional section logs: (a) SW1 section; (b) SW2 section; (c) AC1 section; (d) NE1 section. A5 and A6 in (c) refer to cave measurement stations within Naegeli and others (2014), where it is named 'Crack cave'.

and Pye, 2001). Distributions derived from laser sizing (percentage volume) were calculated as a percentage of the entire sample weight, and for graphical purposes were plotted together with the distributions derived from sieving (percentage weight) after standardization; this has been done to show the range of grain sizes present within different facies, and it is acknowledged that caution is essential when interpreting such datasets derived from different methods (cf. Hoey, 2004). Clast-shape and -fabric data from the matrix-supported diamict were collected following Lukas and others (2013) and Benn (2004), respectively. Samples for stable isotope analysis were either taken from the entirely melted ice blocks following filtering or extracted directly from the sections using an ice screw. All samples were stored in $30 \mathrm{~mL}$ HDPE narrow-neck, screw-top bottles. Analysis was undertaken at the University

Table 1. Key characteristics of sediment and ice facies identified at Tellbreen

\begin{tabular}{|c|c|c|c|}
\hline Sediment/ice facies & $\begin{array}{c}\text { Thickness } \\
\text { m }\end{array}$ & Physical characteristics & Proposed origin \\
\hline Englacial & $>10$ & $\begin{array}{l}\text { White, opaque appearance; bubble-rich; contains alternations of } \\
\text { bubble-rich and bubble-poor ice; very low debris content }\end{array}$ & Meteoric ice \\
\hline Dispersed & $\sim 0.1-2$ & $\begin{array}{c}\text { Variable bubble content, ranging from clear, bubble-free ice to dense, } \\
\text { white clouds of bubbles and intercalated bubble-rich and bubble-poor } \\
\text { layers; low debris-content of }<1 \%(n=4) \text {, largely consisting of suspended } \\
\text { grains, clots or thin laminae of silt-sized material }\end{array}$ & $\begin{array}{l}\text { Strain-induced metamorphism } \\
\text { of englacial facies }\end{array}$ \\
\hline Matrix-supported diamict & $\sim 2-4$ & $\begin{array}{l}\text { Frozen poorly sorted, matrix-supported diamict; contains bubble-free } \\
\text { clear ice lenses and interstitial ice; measured debris content ranges from } \\
\qquad \sim 52 \% \text { to } 80 \%(n=4)\end{array}$ & Frozen subglacial traction till \\
\hline
\end{tabular}


Table 2. Fabric statistics of $S_{2}$ lineation and clast fabric data. Numbers in parentheses refer to numbered sampling sites in Figure $2 d$

\begin{tabular}{lccccccc}
\hline Type/facies & Section & $n$ & $\begin{array}{c}\text { Mean lineation } \\
\text { azimuth }\left(\mathrm{V}_{1}\right)\end{array}$ & $\mathrm{S}_{1}$ & $\mathrm{~S}_{2}$ & $\mathrm{~S}_{3}$ & $\mathrm{~S}_{3} / \mathrm{S}_{1}$ \\
\hline $\mathrm{S}_{2}$ lineation & SW1 and SW2 & 18 & 316.4 & 0.93 & 0.06 & 0.01 & 0.01 \\
$\mathrm{~S}_{2}$ lineation & AC1 & 11 & 307.6 & 0.92 & 0.06 & 0.02 & 0.02 \\
$\mathrm{~S}_{2}$ lineation & NE1 & 14 & 130.8 & 0.93 & 0.05 & 0.01 & 0.01 \\
Diamict (1) & NE1 & 50 & 129.3 & 0.65 & 0.28 & 0.06 & 0.13 \\
Diamict (2) & NE1 & 50 & 109.8 & 0.56 & 0.31 & & 0.23 \\
\hline
\end{tabular}

of Birmingham, UK, on a GV Instruments Isoprime continuous-flow mass spectrometer.

Planar glaciological structures were first identified within the ice caves and measured as strike and dip using a compass/clinometer. These field data were then integrated with the structures mapped on the glacier surface from aerial photographs and classified and coded from $\mathrm{S}_{0}$ upwards based on order of formation, in accordance with structural geology conventions (Hambrey and others, 2005; Roberson and Hubbard, 2010). The dip direction and dip (linear structure) of sheared englacial debris laminae, or 'mineral stretching lineation' (Fleming and others, 2013), were also recorded. All field-measured fabric data were plotted as equal-area stereographic projections using Stereo32 (Röller and Trepmann, 2008), which was also used to calculate fabric statistics $\left(\mathrm{S}_{1}, \mathrm{~S}_{2}\right.$ and $\mathrm{S}_{3}$ eigenvalues, not to be confused with structural glaciology notations) following Benn (2004).

\section{RESULTS}

\section{Facies distribution}

The geographical distribution of the main sediment and ice facies within the SW, AC and NE caves (Fig. 2) is briefly described first to provide some initial context, followed by a detailed description of the physical and isotopic characteristics of the facies (Table 1).

\section{SW cave}

Englacial facies ice is the dominant ice type throughout the SW cave, which is cross-cut by thin debris bands logged as $\mathrm{S}_{2}$ and $\mathrm{S}_{3}$ structures in the SW1 and SW2 sections (see Structural glaciology subsection below; Figs $2 \mathrm{a}$ and $3 \mathrm{a}$ and b). Some of the thicker $S_{3}$ structures contain sorted sediments (Fig. 3a and b).

\section{AC cave}

Englacial facies ice is also the dominant ice type within the AC cave, as shown within the area logged as the AC1 section (Figs $2 \mathrm{~b}$ and $3 \mathrm{c}$ ). $\mathrm{S}_{2}$ and $\mathrm{S}_{3}$ structures cross-cut the englacial facies ice, and some of the thicker $S_{3}$ structures contain sorted sediments (Fig. 3c). Matrix-supported diamict is found at the base of the cave immediately up-glacier of the AC1 section, and small areas of dispersed facies ice were also observed throughout the cave.

\section{NE cave}

The base of the NE cave consists of matrix-supported diamict (Figs $2 \mathrm{~d}$ and $3 \mathrm{~d}$ ). This is overlain by dispersed facies ice, which extends to the cave roof in the NE1 section. There is a large area of sorted sediment close to the cave entrance, and several thinner bands of sorted sediment are found throughout the NE1 section (Fig. 3d).

\section{Sediment facies}

\section{Matrix-supported diamict}

This facies forms the lowermost unit at the NE1 section (Figs $2 \mathrm{~d}$ and $3 \mathrm{~d}$ ), where it ranges in thickness from 2 to $4 \mathrm{~m}$, and consists of frozen, poorly sorted diamict with interstitial ice and small, largely bubble-free clean ice lenses (Table 1; Fig. $4 \mathrm{a}$ and $\mathrm{b}$ ). The diamict is matrix-supported and contains predominantly subangular clasts (Fig. 5a), ranging up to boulder size $(0.5 \mathrm{~m}$ in diameter). The grain-size distribution of the facies is polymodal and displays distinct peaks within silt and sand (Fig. 5b). Debris concentrations vary with height across the thickness of the facies, grading over tens of centimetres from measured values of $52 \%$ close to the contact with overlying ice, in an area where numerous clean ice lenses are visible, to $80 \%$ at $\sim 1 \mathrm{~m}$ depth (Table 1; Fig. 4b). Intermediate debris concentrations of $65 \%$ and $70 \%$ were measured from the area between these two (Fig. 4b). The upper ice-rich area is observed to vary in thickness from $\sim 0.1$ to $1 \mathrm{~m}$ and displays crude stratification highlighted by the presence of ice lenses. This stratification becomes less distinct with depth, and below $\sim 1 \mathrm{~m}$ the facies appears structureless. The debris in this lowermost area contains only interstitial ice and is effectively frozen diamict. The ice-rich parts of this facies could also be described as solid stratified facies ice according to the Hubbard and others (2009) classification. Occasional thin $(\sim 5 \mathrm{~cm})$, horizontally aligned layers of sorted sands and gravel are found both within the diamict and in places at its interface with overlying dispersed facies ice (Fig. 4b). Two clast fabric samples recorded from either end of section NE1 (Fig. 3d) show mean lineation azimuths of $129^{\circ}$ and $109^{\circ}$, and display moderate to weak clustering $\left(\mathrm{S}_{1}\right.$ values of 0.65 and 0.56; Table 2; Fig. 6a and b). Stable isotope analysis of the clean ice lenses and interstitial ice within this facies returned mean values of $-12.11 \%$ o $\left(\delta^{18} \mathrm{O}\right)$, which is statistically distinct from the englacial facies mean values at the $95 \%$ confidence level (i.e. $\pm 2 \sigma$ ), and $-92.66 \%$ o $(\delta \mathrm{D})$, which shows slightly higher values than englacial ice but is not statistically distinguishable at the 95\% confidence level (Table 3; Fig. 7). These data do not show significant linear relationships (e.g. freezing slopes) when plotted co-isotopically. Restricted exposures of similar matrix-supported diamict also occur in AC cave, although in most places the cave floor is obscured by the coarse, poorly sorted bed load of the meltwater stream.

\section{Sorted sediments}

At the left-hand end of the NE1 section, the matrixsupported diamict is in contact with a $\sim 1-2 \mathrm{~m}$ thick band 

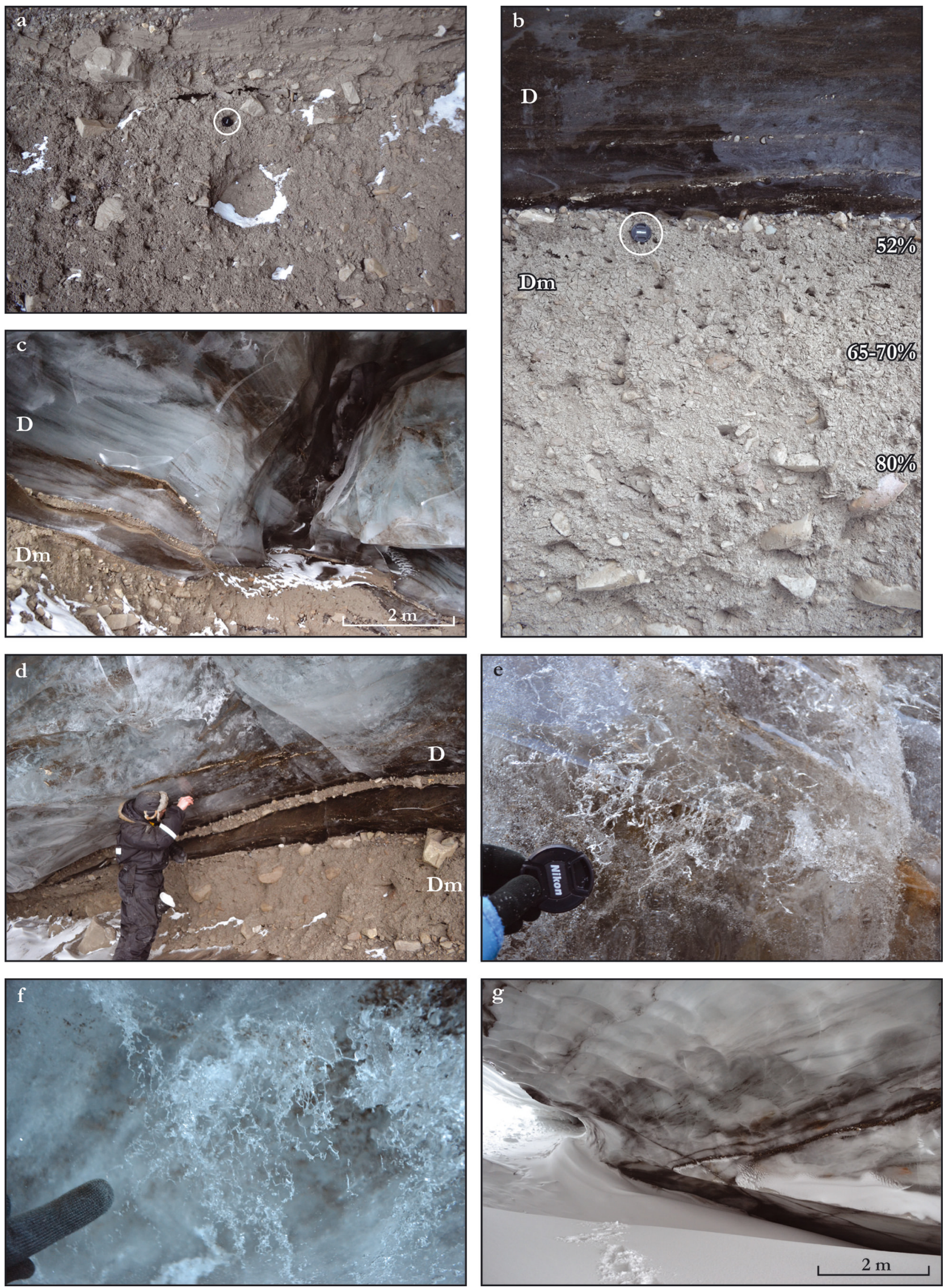

Fig. 4. Examples of sediment and ice facies. (a) Matrix-supported diamict at base of NE cave. Lens cap circled for scale. (b) Matrix-supported diamict (Dm) overlain by dispersed facies (D) in NE cave. Note clean ice lenses within matrix-supported diamict and thin layer of sands and gravels at contact with dispersed facies. Percentages in white are measured debris concentrations (\% by volume). Lens cap circled for scale. (c) Dispersed facies overlying matrix-supported diamict at base of NE cave. (d) Dispersed facies overlying matrix-supported diamict within NE cave. Note areas of both bubble-free and bubble-rich ice. (e) Filament-like bubble structures within clear dispersed facies at NE cave. (f) Filament-like bubble structures within clear dispersed facies towards entrance of AC cave. (g) Englacial ice within SW cave. Note white appearance and evidence for horizontally aligned intercalated layers of bubble-rich and bubble-poor ice. 

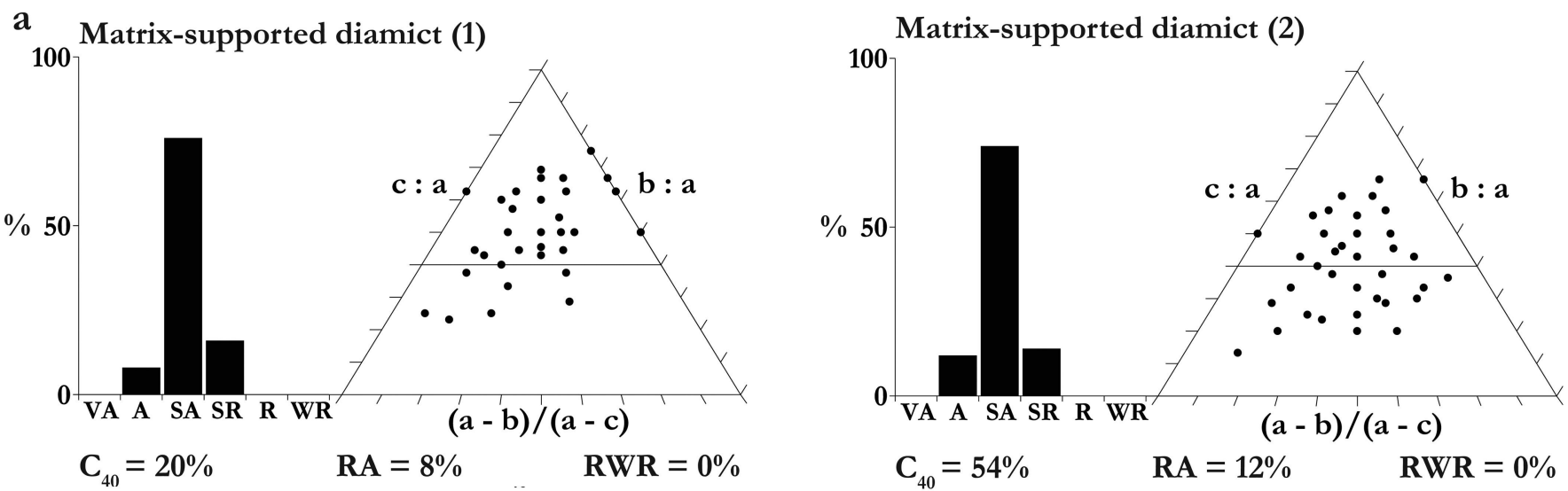

b

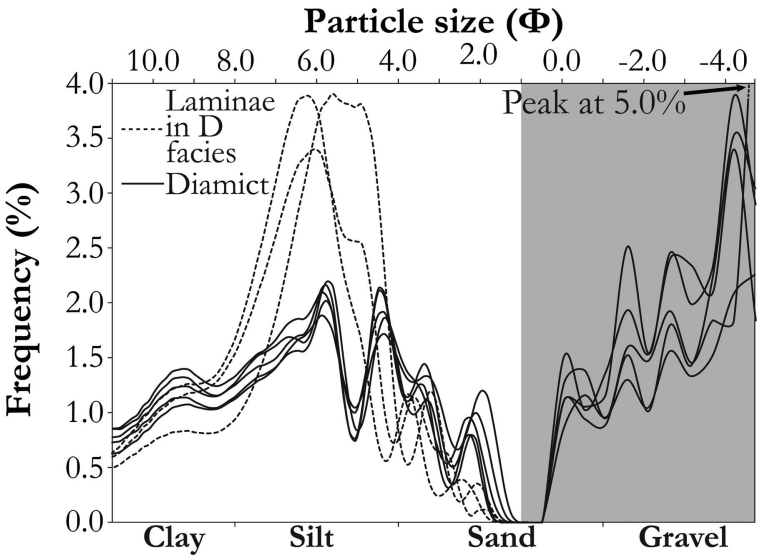

Fig. 5. Sedimentary characteristics of matrix-supported diamict and dispersed ice facies. (a) Clast shape data from matrix-supported diamict at NE1 section plotted on histograms (roundness) and ternary diagrams (shape) generated using the TRI-PLOT spreadsheet (Graham and Midgley, 2000). Each sample is of 50 sandstone clasts. Numbers in parentheses refer to sample numbers in Figure $3 \mathrm{~d}$. (b) Grain-size distributions of matrix-supported diamict (solid line; $n=5$ ) and debris laminae within dispersed facies (dashed line; $n=3$ ) from NE1 section. Troughs in the data are an artefact of graphically combining dry sieving (in shaded area) and laser granulometry methods.

of sorted sediments that extends laterally into glacier ice. The sediments consist of layers of sorted fine sand, interbedded sands and gravels and clast-supported massive gravel (Fig. 3d). The sorted fine sand layers range from 10 to $50 \mathrm{~cm}$ in thickness and display laminations, which in places have been subjected to small-scale folding. These layers are overlain by interbedded coarse sand and fine gravel which dip down-channel at $\sim 30^{\circ}$. Clast-supported and imbricated coarse gravel layers are also present, the largest of which is $\sim 50 \mathrm{~cm}$ thick and extends for $\sim 6 \mathrm{~m}$ laterally. Similar sediment bands were also observed elsewhere in the walls of the NE cave, forming laterally extensive, gently sloping layers that cut across ice foliation and other structures. Examples also occur in the SW and AC caves (Fig. 3).

\section{Ice facies}

\section{Dispersed facies}

The dispersed facies overlies the matrix-supported diamict at the NE1 section (Fig. 3d) and within the AC cave, and is characterized by debris-poor ice with variable bubble

Table 3. Summary of stable isotope data

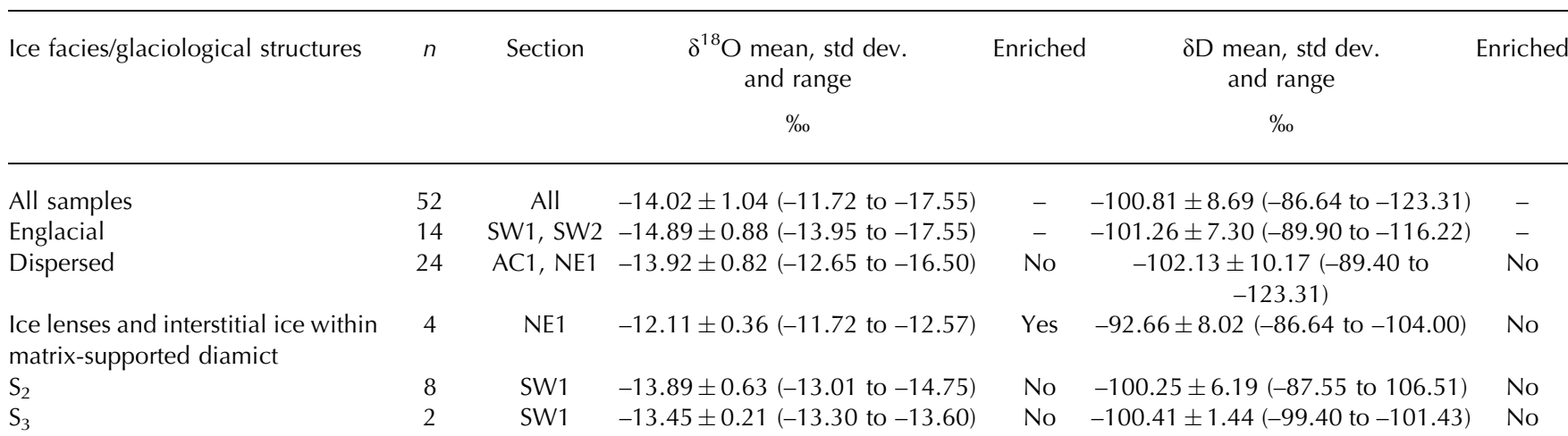

Note: 'Enriched' indicates whether ice facies were enriched in heavy isotopes relative to mean values of $\delta^{18} \mathrm{O}$ and $\delta \mathrm{D}$ for the englacial facies at the $95 \%$ confidence level (i.e. $\pm 2 \sigma)$. 


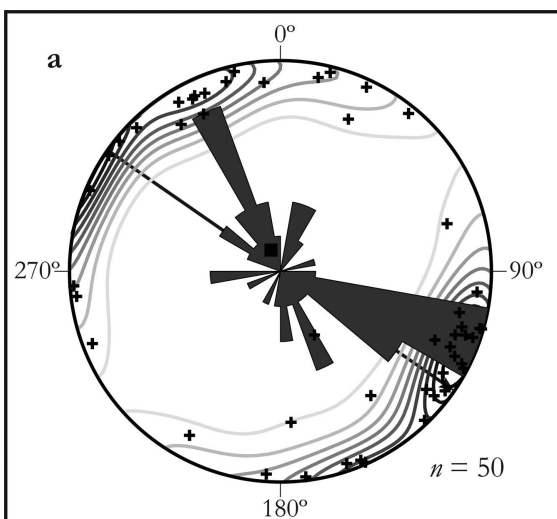

NE1 diamict (1)
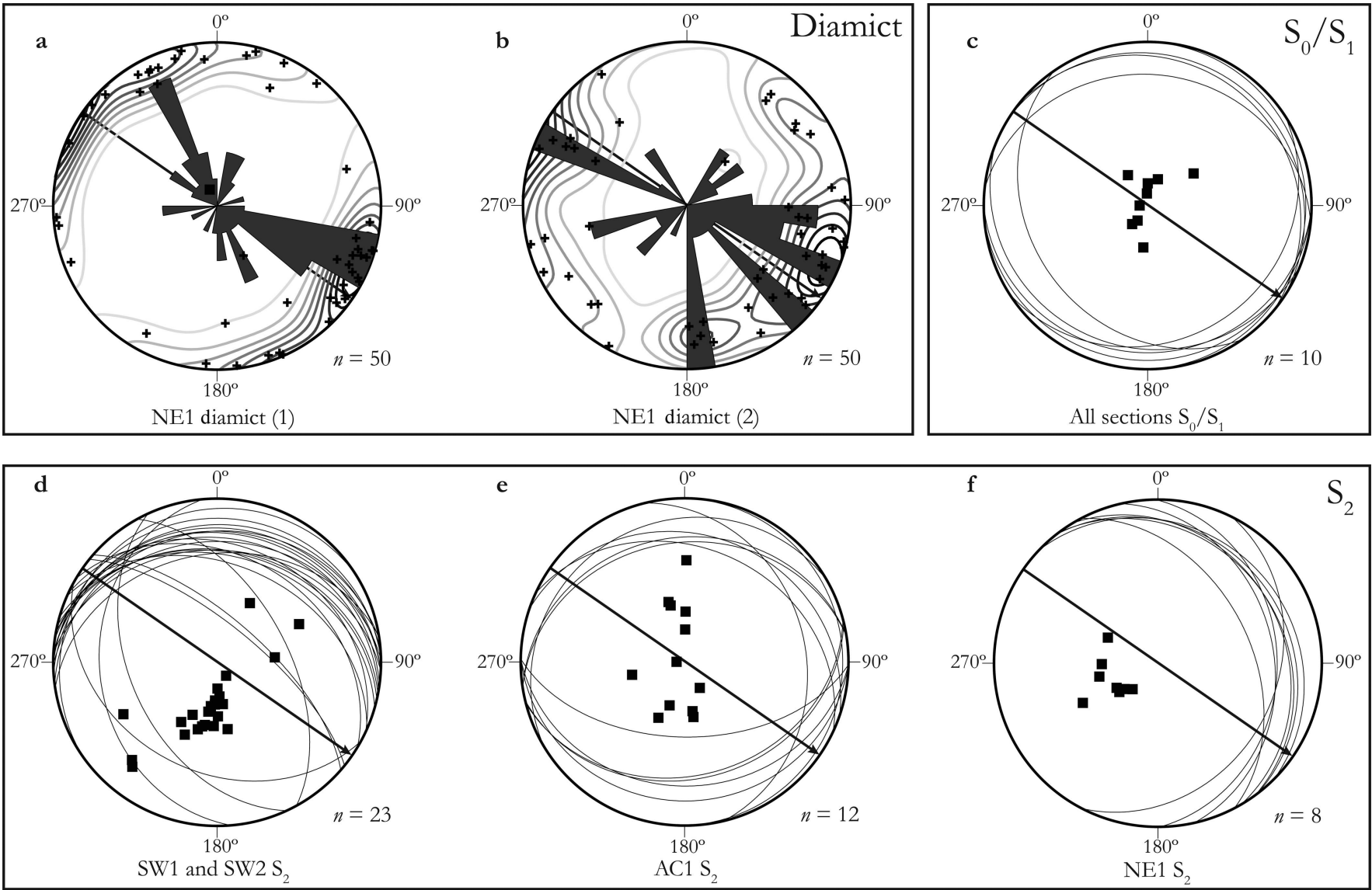

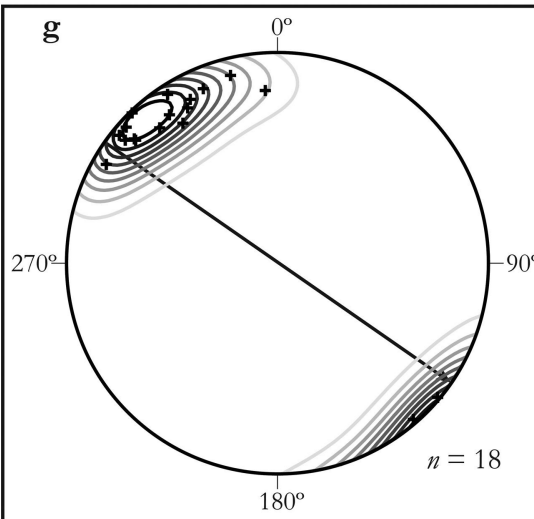

SW1 and SW2 $\mathrm{S}_{2}$ lineation

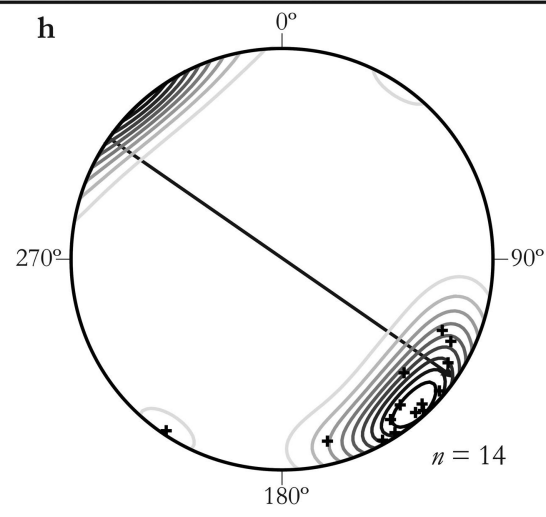

NE1 $\mathrm{S}_{2}$ lineation

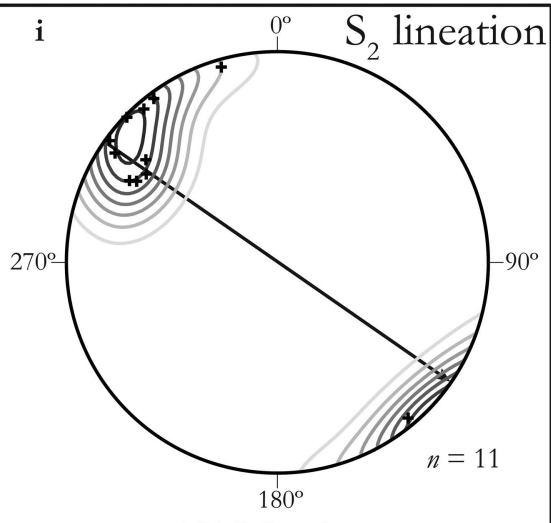

AC1 $\mathrm{S}_{2}$ lineation

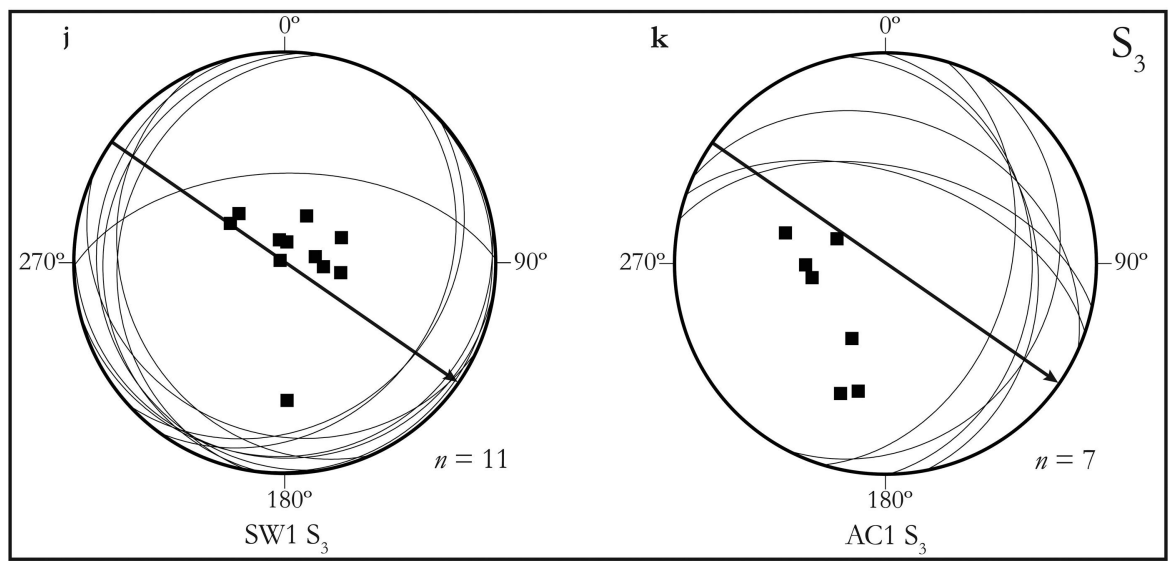

Fig. 6. Lower-hemisphere equal-area stereographic projections and rose diagrams of structural and fabric data within Tellbreen. (a, b) Clast fabric samples of matrix-supported diamict at NE1. Numbers in parentheses refer to numbered sampling sites in Figures $2 d$. (c) $S_{0} / S_{1}$ in $S W 1$, SW2 and AC1. (d) $S_{2}$ in SW1 and SW2. (e) $S_{2}$ in AC1. (f) $S_{2}$ in dispersed facies at NE1. (g) $S_{2}$ lineation in SW1 and SW2. (h) $S_{2}$ lineation in AC1. (i) $S_{2}$ lineation in NE1. (j) $S_{3}$ in SW1. (k) $S_{3}$ in AC1. Structural planes are plotted as great circles while poles to bedding are plotted as solid squares. Black arrow shows centre-line ice flow direction at the terminus. 

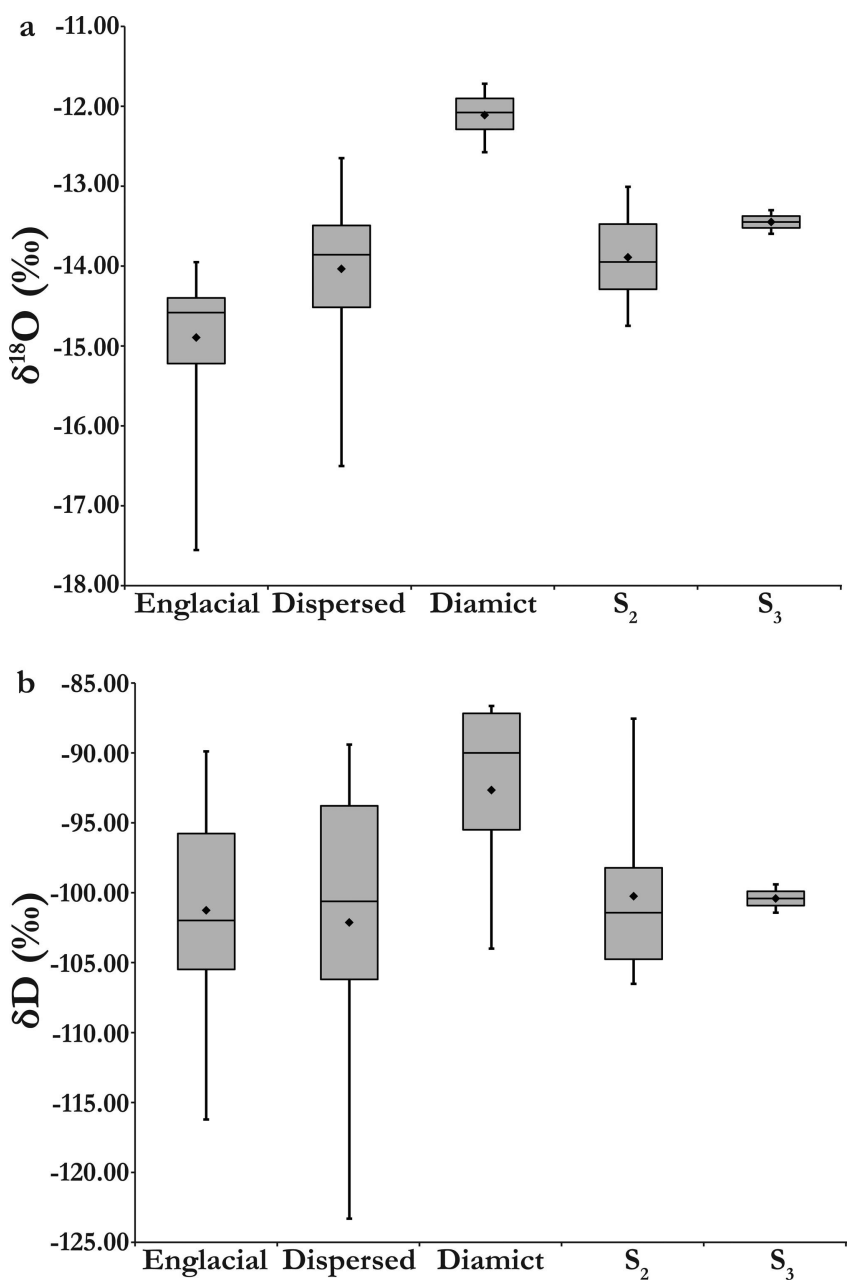

Fig. 7. Box plots of stable isotope analysis of Tellbreen ice facies and glaciological structures showing maximum, upper quartile, median, mean (black diamond), lower quartile and minimum values. (a) $\delta^{18} \mathrm{O}$ composition. (b) $\delta \mathrm{D}$ composition. content and character (Table 1; Fig. 4c and d). The thickness of the facies ranges from $<0.1 \mathrm{~m}$ within the $\mathrm{AC}$ cave to $\geq 2 \mathrm{~m}$ at NE1 (Fig. 3d). The debris within the ice takes the form of suspended grains or clots of predominantly silt-sized fine sediment, occasionally forming thin laminae $(<1 \mathrm{~cm}$; Fig. $5 \mathrm{~b})$ : Debris concentrations of $<1 \%$ were measured at the NE1 section (Table 1). Suspensions of bright orange material were observed in places, and many of the laminae had a strong linear component, characterized by the strong alignment of grains or clots of fine sediment (Fig. 8c). Bubble content and character varies from clear areas, with no or very few bubbles (Fig. 4b), to areas containing dense, white clouds of bubbles and intercalated bubble-rich and bubble-poor layers (Fig. 4c and d). The bubble-poor areas are typically located close to the contact with the underlying frozen diamict (Figs $3 \mathrm{~d}$ and 4b) and often contain filament-like structures of very fine bubbles (Fig. 4e and f). In places, these structures grade into thicker, ribbon-like features, several individual bubbles $(\sim 1-$ $5 \mathrm{~mm}$ diameter) and dense bubble clouds (Fig. 4c). In areas where they coincide, these bubble structures cut across intercalated layers of bubble-rich and bubble-poor ice within the dispersed facies. Stable isotope analysis returned mean compositions of $-13.92 \%$ o $\left(\delta^{18} \mathrm{O}\right)$ and $-102.13 \%$ ( $\left.\delta \mathrm{D}\right)$, and the facies shows slightly heavier values of $\delta^{18} \mathrm{O}$ than englacial ice mean values but these are not statistically distinct at the 95\% confidence level (Table 3; Fig. 7). These data do not display significant linear relationships (e.g. freezing slopes) when plotted co-isotopically.

\section{Englacial facies}

The englacial facies has ubiquitous stratification at centimetre to decimetre scales, in the form of intercalated layers of bubble-rich and bubble-poor ice (Fig. 4e). This layering is visible on the glacier surface as slight colour changes. Apart from the thin debris bands which cross-cut this facies within the SW and AC caves (Figs $2 \mathrm{a}$ and $\mathrm{b}$ and $3 \mathrm{a}-\mathrm{C}$ ), the ice contains only occasional suspended grains and small clots of fine sediment. The englacial facies returned mean stable isotope values of $-14.89 \%$ o $\left(\delta^{18} \mathrm{O}\right)$ and $-101.26 \%$ o $(\delta \mathrm{D})$ (Table 3).

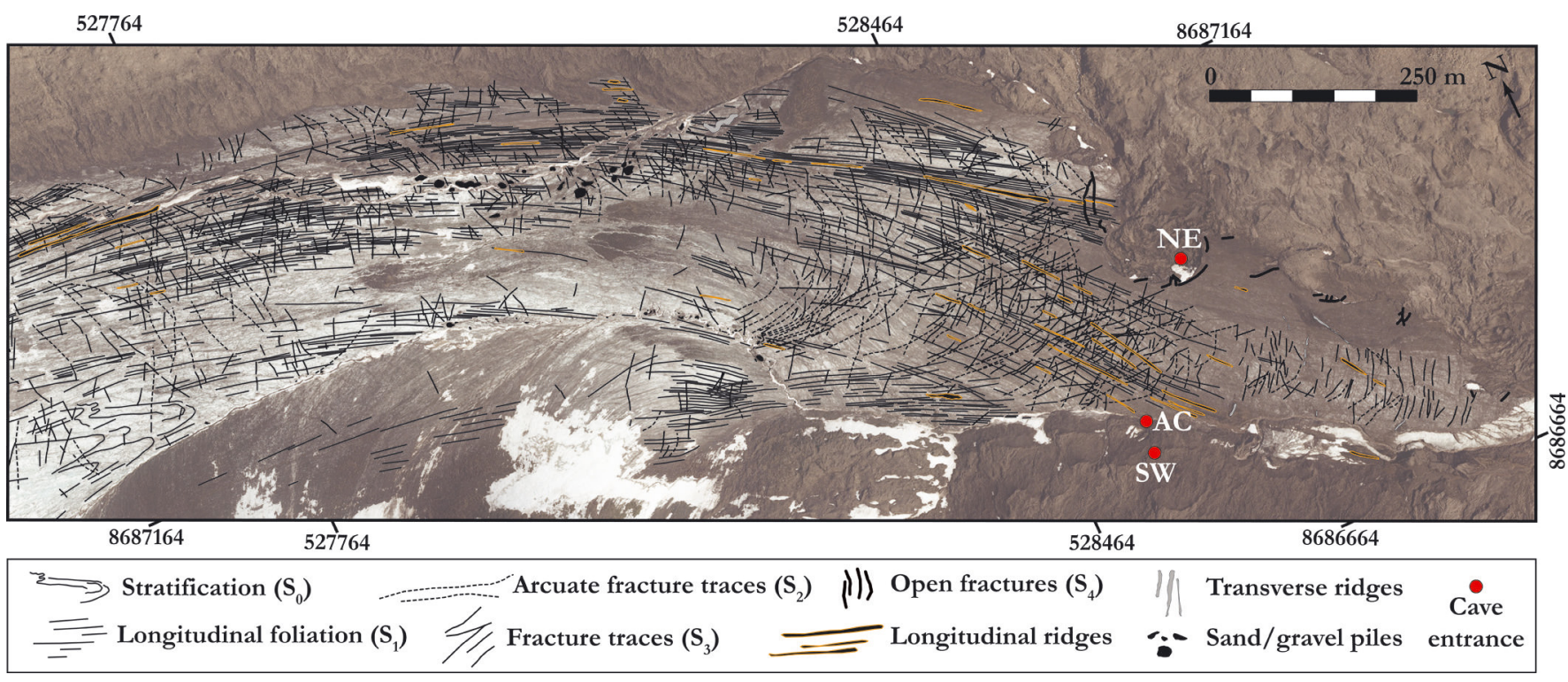

Fig. 8. Structural interpretation of Tellbreen lower tongue from 2009 imagery. Aerial photograph mosaic (S2009_13835 00426 and 00428 ) published with the permission of Norsk Polarinstitutt (NPI). 
Table 4. Summary of principal glaciological structures within Tellbreen

\begin{tabular}{|c|c|c|}
\hline $\begin{array}{l}\text { Planar } \\
\text { glaciological } \\
\text { structures }\end{array}$ & Description & Proposed origin \\
\hline $\mathrm{S}_{0} *$ & $\begin{array}{c}\text { Primary } \\
\text { stratification }\end{array}$ & $\begin{array}{c}\text { Firnification processes in the } \\
\text { accumulation area producing } \\
\text { original layering }\end{array}$ \\
\hline $\mathrm{S}_{1} *$ & $\begin{array}{l}\text { Longitudinal } \\
\text { foliation }\end{array}$ & $\begin{array}{l}\text { Folding of } \mathrm{S}_{0} \text { eventually leading to } \\
\text { isoclinal limbs parallel to ice flow } \\
\text { which intersect with the surface }\end{array}$ \\
\hline $\mathrm{S}_{2}$ & $\begin{array}{c}\text { Arcuate fracture } \\
\text { traces }\end{array}$ & $\begin{array}{c}\text { Shear planes formed in response to } \\
\text { compressional/transpressional stress } \\
\text { regimes }\end{array}$ \\
\hline $\mathrm{S}_{3}$ & Fracture traces & Healed extensional crevasses \\
\hline $\mathrm{S}_{4}$ & Open fractures & Extensional crevasses \\
\hline
\end{tabular}

${ }^{*} \mathrm{~S}_{0}$ and $\mathrm{S}_{1}$ represent end members of a structural continuum.

\section{Structural glaciology}

The planar glaciological structures described in this subsection (Table 4) occur in englacial ice, typically up to several metres above the bed. These structures are observed both within the ice caves (Fig. 3) and on the glacier surface (Fig. 8). The overall distribution of the structures $\left(\mathrm{S}_{0}-\mathrm{S}_{4}\right.$; Table 4) on the glacier surface is as follows: Primary stratification $\left(\mathrm{S}_{0}\right)$ is only identified in the upper part of the lower tongue of Tellbreen, towards the western margin of the glacier (Fig. 8). Longitudinal foliation $\left(\mathrm{S}_{1}\right)$ is ubiquitous across the entire glacier surface and is generally aligned with the dominant ice flow direction. The only exception to this is close to the western margin, where there is a small area of $S_{1}$ structures which are oriented obliquely to the main set. Arcuate fracture traces $\left(S_{2}\right)$ are generally oriented perpendicular to the dominant ice flow direction and are primarily found on the lowermost part of the glacier tongue, where they are distributed across the full width of the glacier. Fracture traces $\left(\mathrm{S}_{3}\right)$ are also aligned perpendicular to flow, and are distributed throughout the lower tongue. Open fractures $\left(\mathrm{S}_{4}\right)$ are only observed towards the eastern margin of the lower glacier tongue (Fig. 8) and high up in the accumulation basins.

Characteristics of each of these structures and their relationships to each other will now be described in more detail based on both the surface mapping (Fig. 8) and investigations within the ice caves (Fig. 3).

\section{$S_{O}$ - primary stratification}

This structure is defined by the alternations of bubble-rich and bubble-poor ice within englacial ice (Figs 4e and 9a and d). This layering appears as slight colour changes on the glacier surface, and in places can be traced as irregular linear features, although these are not identifiable in the lowermost part of the tongue (Fig. 8). Stratification is crosscut by $\mathrm{S}_{2}$ and $\mathrm{S}_{3}$ structures (Fig. 9a and d).

\section{$S_{1}$ - longitudinal foliation}

Linear, flow-parallel stripes on the glacier surface are identified as longitudinal foliation based on their similarity to features mapped as such in other studies (e.g. Hambrey and Dowdeswell, 1997; Hambrey and others, 2005; Roberson and Hubbard, 2010). Longitudinal foliation is closely associated with longitudinal supraglacial ridges mantled by thin $(<5 \mathrm{~cm})$ drapes of angular material (Figs 8 and $9 b)$.

\section{$S_{2}$ - arcuate fracture traces}

The glacier surface displays a number of linear stripes orientated perpendicular and sub-perpendicular to $S_{1}$ structures and ice flow, identified as trace evidence of brittle deformation (Fig. 8). These are subdivided into arcuate fracture traces $\left(S_{2}\right)$ and fracture traces $\left(S_{3}\right)$. Arcuate fracture traces appear on the glacier surface as gently curving linear stripes, often traceable for tens to hundreds of metres (Figs 8 and 9b), and as one set of the thin $(<2 \mathrm{~cm})$ debris bands exposed within the ice caves (Figs 3 and 9). The correlation between the surface and englacial structures is based on their similar characteristics and relationships to other structural elements. Both on the glacier surface and in the ice caves, $S_{2}$ structures (1) rarely cross-cut each other but do intersect on occasion (Figs 8 and 9a); (2) display similarly consistent orientations, with measurements from the SW and AC caves recording dominant orientations of $\sim 350-010^{\circ}$, and within the NE cave $\sim 040-060^{\circ}$ (Fig. $6 \mathrm{~d}-\mathrm{f}$ ); and (3) are cross-cut by $\mathrm{S}_{3}$ structures, which display more variable orientations (Figs 8 and 9a). In the ice caves, some $S_{2}$ structures display centimetre-scale offsets of $S_{0}$ stratification in a vertical direction. The debris within englacial $S_{2}$ structures includes individual grains and small clots of fine material suspended within bubble-poor ice (Fig. 9d and e) with a strong peak in the silt size range (Fig. 5b). In almost all cases the debris displays a strong linear component, and fabric data from these show mean lineation azimuths of $316^{\circ}$ (sections SW1 and SW2), 308 (AC1) and $131^{\circ}$ (NE1), recording a northwest-southeast alignment (Table 2; Fig. $6 \mathrm{~g}-\mathrm{i})$, and display strong clustering $\left(\mathrm{S}_{1}\right.$ values of 0.93 , 0.92 and 0.53 ; Table 2). Stable isotope analysis of ice within the $\mathrm{S}_{2}$ structures shows slightly heavier $\delta^{18} \mathrm{O}$ values than for englacial ice, and lighter values than for the ice lenses and interstitial ice within the diamict, but these values are not statistically distinct at the $95 \%$ confidence level (Table 3; Fig. 7).

\section{$S_{3}-$ fracture traces}

The second group of fracture traces $\left(\mathrm{S}_{3}\right)$ are generally shorter and display more variable orientations than $S_{2}$ structures on the glacier surface (Fig. 9b), and are observed to cross-cut $\mathrm{S}_{0} / \mathrm{S}_{1}, \mathrm{~S}_{2}$ and other $\mathrm{S}_{3}$ structures (Fig. 8). These surface features are correlated to the second set of debris bands within the SW and AC caves, which clearly cross-cut both $\mathrm{S}_{0} / \mathrm{S}_{1}$ and $\mathrm{S}_{2}$ structures (Figs 3 and $9 \mathrm{a}$, e and g) and in places can be directly traced to the surface (Fig. 9c). In addition to orientations, the sediment composition and thicknesses of the $S_{3}$ structures are also more variable than $S_{2}$, ranging from $<1 \mathrm{~cm}$ thick bands of suspended grains and clots of wellsorted silt-sized material (Fig. 9e and g), to $\sim 5-10 \mathrm{~cm}$ thick bands of poorly sorted sandy gravel with up to $2-3 \mathrm{~cm}$ diameter clasts (Fig. 9f). This sediment composition is similar to that within transverse supraglacial ridges on the lower part of the glacier (Fig. 8), which are aligned perpendicular and sub-perpendicular to ice flow direction and in the field take the form of sharp-crested ridges composed of layers of cross-bedded sand and gravels up to cobble size (Fig. 9h). There is no evidence of mineral stretching lineations or shearing within $\mathrm{S}_{3}$ structures. The stable isotope analysis of ice within $S_{3}$ structures returned 

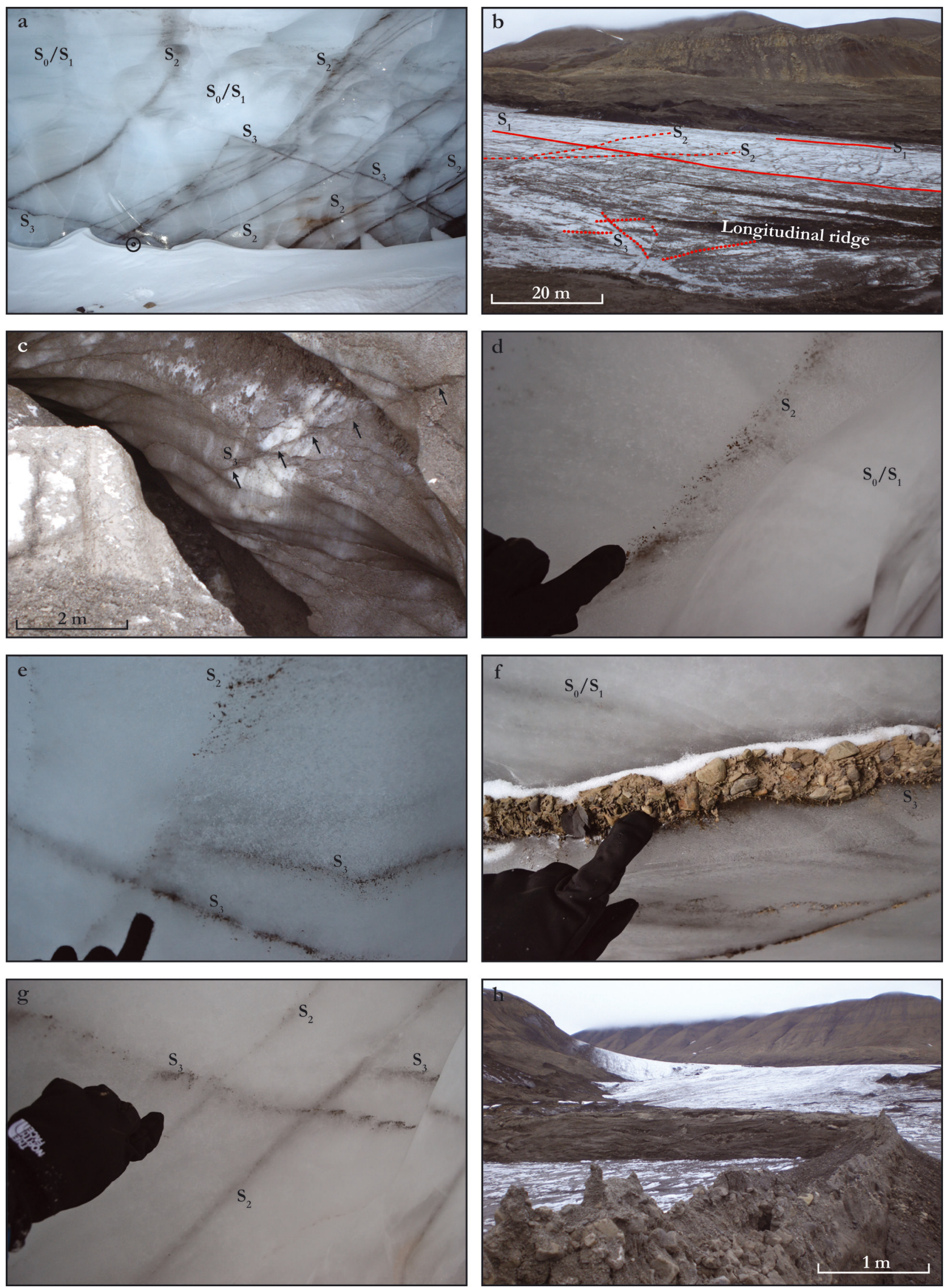

Fig. 9. Details of glaciological structures in Tellbreen. (a) $S_{0} / S_{1}, S_{2}$ and $S_{3}$ structures exposed in $S W$ cave. Note how $S_{3}$ structures cut across $S_{2}$ structures. Lens cap circled for scale. (b) $S_{1}$ (solid lines), $S_{2}$ (dashed lines) and $S_{3}$ (dotted lines) structures exposed on the surface of Tellbreen. Note longitudinal supraglacial ridges. (c) $S_{3}$ structure exposed in side of a meltwater conduit. (d) $S_{0} / S_{1}$ and $S_{2}$ structures within SW cave. Note linear smearing of sediment grains and clots within $S_{2}$ structures. (e) $S_{2}$ and $S_{3}$ structures within SW cave. Note linear smearing of sediment grains and clots within $S_{2}$ structures, which are cut across by $S_{3}$ structures. (f) Poorly sorted sandy gravel within $S_{3}$ structure in SW cave. (g) $S_{3}$ structures cutting across $S_{2}$ structures within SW cave. (h) Sharp-crested transverse supraglacial ridge composed of stratified sand and gravel on lower tongue. Note abrupt right-angled change in orientation. 
slightly heavier values of $\delta^{18} \mathrm{O}$ compared to englacial ice, and lighter values compared to ice within the diamict, but these are not statistically distinct at the $95 \%$ confidence level (Table 3; Fig. 7).

\section{$S_{4}$ - open fractures}

These have a very restricted distribution on the lower tongue and were typically only found in close association with the NE cave complex (Fig. 8). Open fractures also occur in steep areas of the upper accumulation basins (cf. Bælum and Benn, 2011).

\section{INTERPRETATION}

\section{Sediment facies}

\section{Frozen subglacial traction till}

This facies is interpreted as a frozen subglacial traction till (cf. Evans and others, 2006; Benn and Evans, 2010) based on its textural characteristics (poorly sorted, matrixsupported, predominance of subangular clasts), moderate to weakly clustered clast fabric aligned with ice flow (Table 2; Fig. 6a and b), and evidence for winnowing at the ice/bed interface in the form of sorted sand and gravel layers. The lowermost $\sim 0.5-1 \mathrm{~m}$ of the facies at the NE cave was observed to be almost entirely frozen diamict with very little ice content (Fig. 4b), and, in conjunction with the location of the cave close to the glacier terminus, it is concluded that the NE1 section is at the glacier bed. The ice lenses in the upper part of the diamict are interpreted as segregation lenses formed from the till pore water, and relatively low debris contents measured in these areas $(\sim 50 \%)$ indicate that the till was highly saturated and probably dilated close to the ice/bed interface (Evans and others, 2006). The vertical gradation in debris content, which increases in a downwards direction, likely reflects a decrease in till dilatancy. It seems likely that freezing was initiated from the glacier ice above, leading to the progressive downwards migration of the freezing front (cf. Christoffersen and others, 2006) into the underlying diamict, forming ice lenses in the upper, more dilated parts of the facies and less-ice-rich frozen diamict towards the base. The results from stable isotope analysis demonstrate that the ice lenses are enhanced in heavy ${ }^{18} \mathrm{O}$ isotopes relative to englacial facies ice (Table 3; Fig. 7), which is consistent with ice formation through refreezing of water in close association with a debris-rich bed (cf. Lawson, 1979; Hubbard and Sharp, 1993; Iverson and Souchez, 1996).

\section{Glacifluvial sediments}

The sorted sediments are interpreted as glacifluvial deposits. The cross-cutting relationship between the sorted sediment bands and the surrounding glacier ice indicates that they are superimposed upon, but not directly related to, the exposed sequence of ice facies and frozen diamict. One interpretation for the formation of the bands is as late-stage sediment infills of cut-and-closure conduits that progressively incised downwards and laterally through the glacier ice and into the bed, described in more detail by Naegeli and others (2014). A second possible origin for the sediments is based on interpretations by Evans (1989) of similar discrete pockets of glacifluvial sediments within marginal ice at several glaciers on Ellesmere Island, Canadian High Arctic. At these sites, the presence of glacifluvial sediments was suggested to relate to the lateral incision of ice-marginal meltwater channels into glacier ice and the subsequent accumulation of sorted sediments within ponded areas. The lateral incision of the channels destabilizes the ice margin, resulting in block collapse and, if the glacier is advancing, apron entrainment (Evans, 1989). This interpretation is consistent with observations from the NE cave, where the northeast ice-marginal channel has incised laterally into the ice margin, leading to localized destabilization and progressive collapse of the cave roof.

In a few cases, thin bands of sand and gravel appear to have formed by other processes. These include the thin, conformable layers of sorted sediment at the contact between the frozen diamict and overlying dispersed facies ice at the NE1 section (Figs 3d and 4c), which are interpreted as evidence for winnowing at the ice/bed interface, and poorly sorted sand and gravel within some $\mathrm{S}_{3}$ glaciological structures, described below in the Structural glaciology subsection.

\section{Ice facies}

Dispersed facies: metamorphosed basal ice

Dispersed facies ice has been described from the basal ice sequences of several glaciers (Lawson, 1979; Larsen and others, 2010; Cook and others, 2011), and has also been referred to as 'clotted facies' ice (Knight, 1987; Sugden and others, 1987; Knight and Knight, 1994) and 'clear facies' ice (Sharp and others, 1994; Hubbard and Sharp, 1995; Hubbard and others, 2000). Cook and others (2011) highlighted that these facies are all descriptively similar, but are interpreted to have formed by a range of processes, with current interpretations favouring either a primarily sedimentary (e.g. Lawson, 1979; Knight, 1987; Sugden and others, 1987) or tectonic (e.g. Sharp and others, 1994; Hubbard and others, 2000; Waller and others, 2000; Cook and others, 2011) origin. At Tellbreen, the evidence is most consistent with a tectonic interpretation for the dispersed facies, characterized by strain-induced metamorphism close to the bed (e.g. Knight, 1997; Hubbard and others, 2000; Waller and others, 2000; Cook and others, 2011). The bubble-poor areas are consistent with widespread melting and refreezing at grain boundaries and associated gas expulsion, caused by enhanced ice deformation and strain heating consistent with warm-based conditions (Kamb and LaChapelle, 1964; Blatter and Hutter, 1991; Hubbard and Sharp, 1995; Hubbard and others, 2000). This process provides an explanation for the bubble structures observed within the dispersed facies, which are characterized by fine bubble strands tracing the outline of ice crystals (Fig. 4e and f), consistent with a routing of gas around grain boundaries. Bubble-rich areas, in places displaying stratification not dissimilar to that within englacial ice (Fig. 4c), may represent preserved remnants of the latter facies where gas expulsion was incomplete (cf. Hubbard and Sharp, 1995). The dispersed ice immediately overlying the frozen diamict, and therefore at the inferred ice/bed interface, typically has the lowest bubble content (Fig. 4b), indicating that this is where metamorphism was most effective. The fine-grained debris within the dispersed facies is inferred to represent the migration of muddy water within the vein network between ice crystals in the basal zone (Lliboutry, 1993; Knight and Knight, 1994). The debris is likely to have been sourced from the underlying saturated till, and its elevation into the dispersed facies suggests that it was probably highly pressurized in order to be forced upwards into the vein 
network, indicating temperate conditions in the basal zone characterized by the availability and mobility of subglacial meltwater in close association with the debris-rich bed. The occasional suspensions of bright orange material within the clear ice are characteristically similar to precipitates of iron oxyhydroxide described at other sites on Svalbard (Hodson and others, 2008). The strong linear component to the debris laminae was also observed by Fleming and others (2013) and these were interpreted as stretching lineations, formed by the realignment of debris about an axis under high-strain conditions. Stretching lineations on the planar surface of laminae at the NE cave display strong evidence of shear in a direction sub-parallel to ice flow (Table 2; Fig. 6k), in agreement with clast fabric data from the underlying diamict (Table 2; Fig. 6a and b).

Stable isotope results for the dispersed facies show that values for $\delta^{18} \mathrm{O}$ are slightly heavier than those for englacial ice, but are not statistically distinct at the 95\% confidence level (Table 3). These data do not form a freezing slope when plotted co-isotopically, indicating that the facies has not formed by the refreezing of parent water from a single source with specific isotopic composition (Souchez and others, 1988). This may instead reflect multiple melting and partial refreezing events at grain boundaries as part of the metamorphism process (Sharp and others, 1994). Souchez and others (1988) suggested that this may produce high ranges in $\delta^{18} \mathrm{O}$ and $\delta \mathrm{D}$ values (e.g. $3.85 \%$ and $33.91 \%$, respectively, measured for the dispersed facies (Table 3$)$ ). The explanation for this is as follows: While no fractionation occurs upon initial melting of existing ice, fractionation occurs upon the refreezing of the water thereby produced, creating new ice that is initially heavy and subsequently progressively lighter than the composition of the initial liquid. Thus, a high range of sample compositions in $\delta^{18} \mathrm{O}$ and $\delta \mathrm{D}$ would be consistent with differential degrees of refreezing occurring at the sample scale within the dispersed facies. If a small amount of last-refrozen water is also lost from the facies then this can explain its slightly heavier isotopic composition relative to that of its proposed parent (englacial facies) ice.

\section{Englacial facies: meteoric ice}

This facies is interpreted as meteoric ice formed by the firnification of snow in the glacier's accumulation area, with the alternating bubble-poor and bubble-rich layers reflecting seasonal melting and refreezing (cf. Hambrey, 1975; Hambrey and Dowdeswell, 1997). The ${ }^{18} \mathrm{O}$ composition of englacial ice is similar to values for recently formed meteoric ice within the Lomonosovfonna ice core, located $\sim 60 \mathrm{~km}$ to the northeast (Divine and others, 2008). Aside from the thin debris bands (Fig. 3), the little scattered debris that exists within the ice probably originated as wind-blown dust (e.g. Lawson, 1979; Sharp and others, 1994; Hubbard and Sharp, 1995; Larsen and others, 2010).

\section{Structural glaciology}

Primary stratification $\left(S_{0}\right)$ and longitudinal foliation $\left(S_{1}\right)$ Although $S_{0}$ and $S_{1}$ structures have been mapped as separate features, in accordance with other structural glaciology studies (e.g. Hambrey and Dowdeswell, 1997; Hambrey and Glasser, 2003; Hambrey and others, 2005; Roberson and Hubbard, 2010), we suggest that these probably represent two end members of the same structure rather than distinct features. Primary stratification $\left(\mathrm{S}_{0}\right)$ describes the layers of bubble-rich and bubble-poor ice formed through firnification processes in the accumulation area (cf. Hambrey, 1975; Hambrey and Dowdeswell, 1997) and is inferred to be the primary structure in the glacier (Table 4). When it initially forms, this layering is likely to be broadly horizontal and display only slight undulations related to the formation of seasonal snow layers, but will become progressively deformed and folded as the result of flow from the accumulation area. Folds increase in tightness as the ice converges in the narrow confines of the lower glacier tongue and is subjected to lateral compression. Eventually the original layering $\left(\mathrm{S}_{0}\right)$ is folded to such an extent that the limbs become isoclinal and parallel to glacier flow. Where the hinge lines of the isoclinal folds intersect the glacier surface, they form linear stripes, mapped as longitudinal foliation or $\mathrm{S}_{1}$ structures (e.g. Hambrey and Dowdeswell, 1997; Hambrey and Glasser, 2003; Roberson and Hubbard, 2010). As with any continuum, some structural elements must exist between the two end members; at Tellbreen, this is represented by the bubble stratification within the englacial ice facies (Fig. 4e), which was measured to dip gently in various directions within the SW and AC caves (Fig. 6c). As this has clearly been subjected to some degree of folding during transport from the accumulation area to the glacier front, this layering was recorded as $\mathrm{S}_{1}$ structures, although in reality it is perhaps unnecessary to distinguish between the two as they represent the same structure.

Longitudinal supraglacial ridges, which are closely associated with longitudinal foliation, are interpreted as debris septa (cf. Eyles and Rogerson, 1978) that have formed through the same process. The debris was probably entrained as rockfall layers within stratification (Eyles and Rogerson, 1978; Hambrey and Glasser, 2003; Roberson and Hubbard, 2010), which has then been tightly folded and melted out at the glacier surface as flow-parallel ridges; this interpretation is supported by the predominantly angular debris within the debris septa.

\section{Arcuate shear planes $\left(S_{2}\right)$}

Similar to Roberson (2008) and Roberson and Hubbard (2010), $S_{2}$ arcuate fracture traces are interpreted as shear planes based on the evidence that: (1) they cut across $S_{0} / S_{1}$ layering at low angles and in places displace it vertically, and (2) the fine material within $S_{2}$ has a strong linear component (Fig. 9d), or stretching lineation (Fleming and others, 2013), indicative of shear in the direction of ice flow (Table 2; Fig. 9i-k). It has been suggested that the development of these types of structures may be facilitated by the presence of pre-existing planar structural weakness (e.g. Hambrey and Müller, 1978; Evans and Rea, 1999; Rea and Evans, 2011), such as healed crevasses (e.g. $S_{3}$ fracture traces); the similar character and sedimentological compositions of $S_{2}$ and $S_{3}$ structures indicate that this may be the case at Tellbreen. The heavier $\delta^{18} \mathrm{O}$ values than for englacial ice may reflect ice formed from water from a variety of sources and therefore with varying initial isotopic compositions (i.e. from an open hydrological system) which freezes in situ in a closed system (Ensminger and others, 2001). The $\delta^{18} \mathrm{O}$ values are also similar to the composition of dispersed ice, which is interpreted to result from strain-induced metamorphism of englacial ice and associated processes of recrystallization, partial melting and expulsion of gases (Kamb and LaChapelle, 1964; Sharp and others, 1994; Hubbard and Sharp, 1995). It is possible that metamorphism 
of this type also occurred within $\mathrm{S}_{2}$ structures, which contain largely bubble-free ice and display evidence of shear. However, caution is advised because the width of the extracted samples $(\sim 2 \mathrm{~cm})$ is similar to that of the structures sampled, making it possible that ice from outside the structures was extracted in some cases, and so this inferred process may not apply to the entire dataset.

\section{Crevasse traces $\left(S_{3}\right)$}

Fracture traces are interpreted as healed fractures or crevasses which opened in response to extensional flow within the glacier (cf. Hambrey, 1976; Hambrey and others, 2005). $S_{3}$ fracture traces cross-cut $S_{2}$ shear planes both on the surface and in section, indicating that their formation postdates that of $\mathrm{S}_{2}$ structures. Fracture traces display variable orientations with a predominant alignment perpendicular and sub-perpendicular to ice flow (Figs $6 \mathrm{j}$ and $\mathrm{k}$ and 8), which is consistent with extensional transverse crevassing, and dip at angles varying from $008^{\circ}$ to $055^{\circ}$. The sediment content of these structures can be explained as injections of meltwater of varying turbidities into fractures and crevasses under conditions of extensional flow and high basal water pressures, as has been observed at Matanuska Glacier, Alaska (Ensminger and others, 2001), and described from Skeiðarárjökull, Iceland (Bennett and others, 2000). Similar to Ensminger and others (2001), it appears that many of these crevasses could be better described as narrow cracks or fractures, which may not open much wider than millimetres, into which thin films or sheets of pressurized turbid water are injected. The preservation of the debris within the structures is indicative of in situ freezing, perhaps associated with conductive cooling from surrounding colder ice and/or fracture closure (cf. Ensminger and others, 2001). The relatively low dip angles of these structures are inconsistent with the vertical crevasses/fractures traditionally associated with extensional flow (cf. Rea and Evans, 2011), which indicates they may have been reoriented since formation (Evans and Rea, 1999; Rea and Evans, 2011). The slightly heavier values of $\delta^{18} \mathrm{O}$ compared to englacial ice and lighter values compared to the frozen diamict (Table 3; Fig. 7) are similar to the findings of Ensminger and others (2001) for debris bands at Matanuska Glacier. This may indicate formation of ice from initial parent waters from an open hydrological system by in situ closed system freezing (Ensminger and others, 2001), although caution is advisable as this is based on limited sampling $(n=2)$. In addition, as with the $\mathrm{S}_{2}$ structures, the similar widths of the extracted samples and the structures mean it is also possible that some ice from outside the $S_{3}$ structures was sampled. The thicker bands of sand and gravel in the SW cave are less common but are interpreted to be formed through the same process. No features similar to the coarser $S_{3}$ bands were described by Ensminger and others (2001), but they share sedimentary characteristics (poorly sorted sandy gravel) with features interpreted as upwardly injected hydrofracture structures at the bed of Kuannersuit Glacier, a surge-type glacier in West Greenland (Roberts and others, 2009). The transverse supraglacial ridges composed of sand and gravel are suggested to result from the melting-out of infilled fractures, although no direct link could be made between the two apart from similar sediment compositions and ridge orientations. The sharp-crested transverse ridge displaying a prominent right-angle change of direction (Fig. 9h) is consistent with pressurized basal meltwater exploiting intersecting crevasses at a higher level in the glacier, as suggested by Evans and Rea (1999) for the formation of concertina or zigzag eskers associated with surge-type glaciers.

\section{Open crevasses $\left(S_{4}\right)$}

Open fractures are extensional crevasses and on the lower glacier tongue are closely associated with the NE cave complex, where the ice margin has been gradually undercut by the northeastern lateral conduit (Fig. 8). Crevasses observed in the steepest parts of the upper basins represent bergschrund-type fracturing (cf. Bælum and Benn, 2011).

\section{DISCUSSION}

\section{Frozen till/basal ice formation}

The formation of the basal sequence at Tellbreen, comprising frozen matrix-supported diamict overlain by dispersed facies ice, can be directly linked to the flow of warm-based ice. The frozen diamict is inferred to have originated as a saturated subglacial traction till, demonstrated by the high ice content in the form of both interstitial ice and small ice lenses. The ice content reflects the freezing of subglacial meltwater stored within the pore spaces of the basal till (Christoffersen and others, 2006) and the development of segregation ice lenses (Waller and others, 2000; Christoffersen and Tulaczyk, 2003). The availability of water is also demonstrated by the thin layers of sand and gravel (glacifluvial sediments) at the boundary between the diamict and dispersed facies ice, reflecting the movement of water at the ice/bed interface. These observations are consistent with the bed being at the pressure-melting point, as basal melting under warm-based conditions would allow meltwater to saturate the underlying permeable bed. Freezing of the saturated till is likely to have occurred as a cold wave or 'freezing front' propagated downwards through the thinning lower tongue (e.g. Bjørnsson and others, 1996). The vertical gradation in ice/ debris content within the facies (Fig. 4b) may be the result of progressive freeze-on as the freezing front extends downwards into the till, forming segregation ice lenses close to the ice/bed interface (e.g. Christoffersen and Tulaczyk, 2003). The gradation could also be the product of decreasing efficiency of meltwater percolation with depth, perhaps as distance from the source increases and as the sediment itself changes (e.g. in degree of consolidation or pore development and connectivity (cf. Christoffersen and others, 2006)). This would produce a more saturated basal till layer (i.e. higher pore-water content) closer to the ice/bed interface, creating a frozen till with higher ice content towards the contact with overlying ice (Fig. 4b).

The stable isotope data from ice lenses within the diamict show that it has been enhanced in heavy ${ }^{18} \mathrm{O}$ isotopes relative to englacial facies ice (Table 3; Fig. 7), which is interpreted as evidence that it formed by the refreezing of highly saturated debris (cf. Lawson, 1979; Hubbard and Sharp, 1993; Iverson and Souchez, 1996). It has been demonstrated that ice formed from refreezing of a localized parent water source, or closed-system freezing (Knight, 1997; Cook and others, 2010), should produce a freezing slope with a lower gradient than englacial ice when plotted on a co-isotopic graph (Souchez and Jouzel, 1984); however, this is not the case for the ice lenses within the frozen diamict at Tellbreen. An explanation for this is that the parent water was not from a single, localized source, but reflects a range of different sources with variable original 
isotopic compositions (Hubbard and Sharp, 1993, 1995; Sharp and others, 1994; Knight, 1997). This situation is consistent with the production of water through net basal melting across large parts of the bed that are at the pressuremelting point, saturating subglacial debris with water from various sources. The frozen diamict samples plot at the heavier end of the isotopic spectrum (Fig. 7), which indicates that the facies, or at least the parts of the facies sampled, formed during the early stages of the freezing process (Sharp and others, 1994; Knight, 1997).

One of the main characteristics of dispersed facies ice is its largely bubble-poor nature, with some areas entirely devoid of bubbles. These areas are typically adjacent to the contact with the frozen till, which underlies dispersed facies ice in most cases (Fig. 4b). This is interpreted as the result of strain-induced metamorphism of englacial ice close to the bed (Hubbard and others, 2000) due to intense and variable shear, resulting in melting and refreezing at grain boundaries and the expulsion of gas (Lliboutry, 1993) away from the shear zone. Evidence for the expulsion of gas takes the form of thin filaments of bubbles routed along crystal boundaries which extend from the area of bubble-free dispersed ice (Fig. 4d). Intense and variable shear within this zone would promote strain heating of the ice, consistent with the presence of temperate ice at the bed (Blatter and Hutter, 1991), and therefore warm-based conditions. The second main characteristic of dispersed facies ice is the presence of individual grains or small clots of typically siltsized material; this is inferred to be thin films of muddy water sourced from adjacent saturated subglacial debris which have been squeezed along the intercrystalline vein network (Knight and Knight, 1994) in a manner similar to the expelled gases. The melting and refreezing events and movement of muddy water and gases are envisaged to effectively occur in a wet (temperate) 'mushy' zone (cf. Fowler, 1984) at the base of the englacial ice, where gas and pressurized muddy water are allowed to migrate through the vein network. This zone is likely to have partly developed due to strain heating close to the ice/bed interface, increasing the temperature of the ice to the pressure-melting point and providing an additional internal source of meltwater (Blatter and Hutter, 1991).

The preserved basal sequence provides compelling support for Tellbreen having undergone a thermal switch from a polythermal regime, when large parts of the bed were at the pressure-melting point, to a cold-based thermal regime, characterized by extremely low flow velocities (personal communication from C. Bøggild, 2012) and large parts (if not all) of the glacier being frozen to its bed (cf. Bælum and Benn, 2011).

\section{Development of glaciological structures}

Evidence for former dynamic flow activity of Tellbreen is also provided by the sequential development of glaciological structures, illustrated schematically in Figure 10, which records the passage of a 'parcel' of ice from the accumulation area to the glacier front.

\section{Primary stratification and longitudinal foliation}

The development of primary stratification $\left(\mathrm{S}_{0}\right)$ occurs in the accumulation area as englacial ice forms due to seasonal firnification processes (Fig. 10a; Hambrey and others, 2005). There is considerable evidence of the deformation of stratification, typically in the form of (1) folding accompanied by simple shear due to lateral compression, which eventually leads to the formation of $\mathrm{S}_{1}$ longitudinal foliation as stratification is at first gently (Fig. 10b) and then more tightly (Fig. 10c) folded in response to compressive stresses caused by a change in flow geometry (e.g. from accumulation area to topographically confined tongue); (2) offset layers of $S_{0} / S_{1}$ due to faulting associated with shear plane development (Fig. 10d); and (3) the erasing of layering due to intense shearing and strain-induced metamorphism of englacial ice close to the glacier bed, which causes the expulsion of gases (e.g. from bubble-rich layers) along grain boundaries and forms dispersed facies ice (Fig. 10e). Rockfall debris buried within primary stratification in the accumulation area (Fig. 10a), which is transferred to the lower tongue and breaches the surface as a result of folding, forms longitudinal supraglacial ridges or debris septa (Figs 8, 9a and 10c). While this transfer of mass remains active (i.e. ice is flowing, however slowly), the folding of stratification and development of foliation will also continue and, therefore, some of these structures may, for a little while longer at least, be actively forming (cf. Hambrey and others, 2005).

\section{Arcuate shear planes}

Arcuate shear planes $\left(\mathrm{S}_{2}\right)$ are located on the lower tongue towards the glacier front (Fig. 8), and in the ice caves are observed to offset primary stratification/longitudinal foliation $\left(\mathrm{S}_{0} / \mathrm{S}_{1}\right)$ but not crevasse traces $\left(\mathrm{S}_{3}\right)$, indicating that formation of $S_{2}$ pre-dates that of $S_{3}$ (Fig. 10d). The development of shear planes within polythermal valley glaciers is consistent with longitudinal compression at the margin leading to brittle failure and thrusting (Hambrey and others, 2005; Roberson and Hubbard, 2010), and at Tellbreen this is supported by the vertical displacement of $\mathrm{S}_{0} / \mathrm{S}_{1}$ across $\mathrm{S}_{2}$ planes, indicating high compressive stresses parallel to ice flow direction (Souchez, 1967; Rees and Arnold, 2007). However, the predominant orientation of $S_{2}$ structures measured at the SW sections shows an approximate offset of $20^{\circ}$ relative to ice flow direction (Fig 6d), rather than the perpendicular relationship that might be expected in a purely compressional zone. The presence of sub-horizontal stretching lineations along these fractures (Fig. 6g) reveals that, rather than purely through dip-slip movement, strain along these fractures has been accommodated through a component of strike-slip (e.g. Fleming and others, 2013). Thus, the orientation of these structures suggests that the marginal areas of the glacier have experienced a transpressional stress regime (cf. Twiss and Moores, 2007; Fleming and others, 2013). The development of shear planes may be facilitated by the presence of preexisting structural weaknesses, such as fractures relating to reoriented healed crevasses (Nye, 1952; Hambrey and Müller, 1978; Rea and Evans, 2011), which are ubiquitous on the lower tongue of Tellbreen $\left(\mathrm{S}_{3}\right.$ fracture traces; Fig. 8). The similar character and sediment composition of both $\mathrm{S}_{2}$ and $S_{3}$ structures appears to provide support for this, particularly as $S_{2}$ structures display evidence for shear and $\mathrm{S}_{3}$ structures do not, indicating that the former may have developed through the reorientation and shearing of the latter (Fig. 10d). However, in the caves, $S_{3}$ crevasse traces cut across and are not offset by $\mathrm{S}_{2}$ shear planes, demonstrating that $S_{3}$ formed after $S_{2}$ structures. The implications of this are that either: (1) $S_{2}$ shear planes represent an entirely new generation of structures unrelated to any inherited weaknesses (e.g. Glasser and others, 2003; Roberson and 


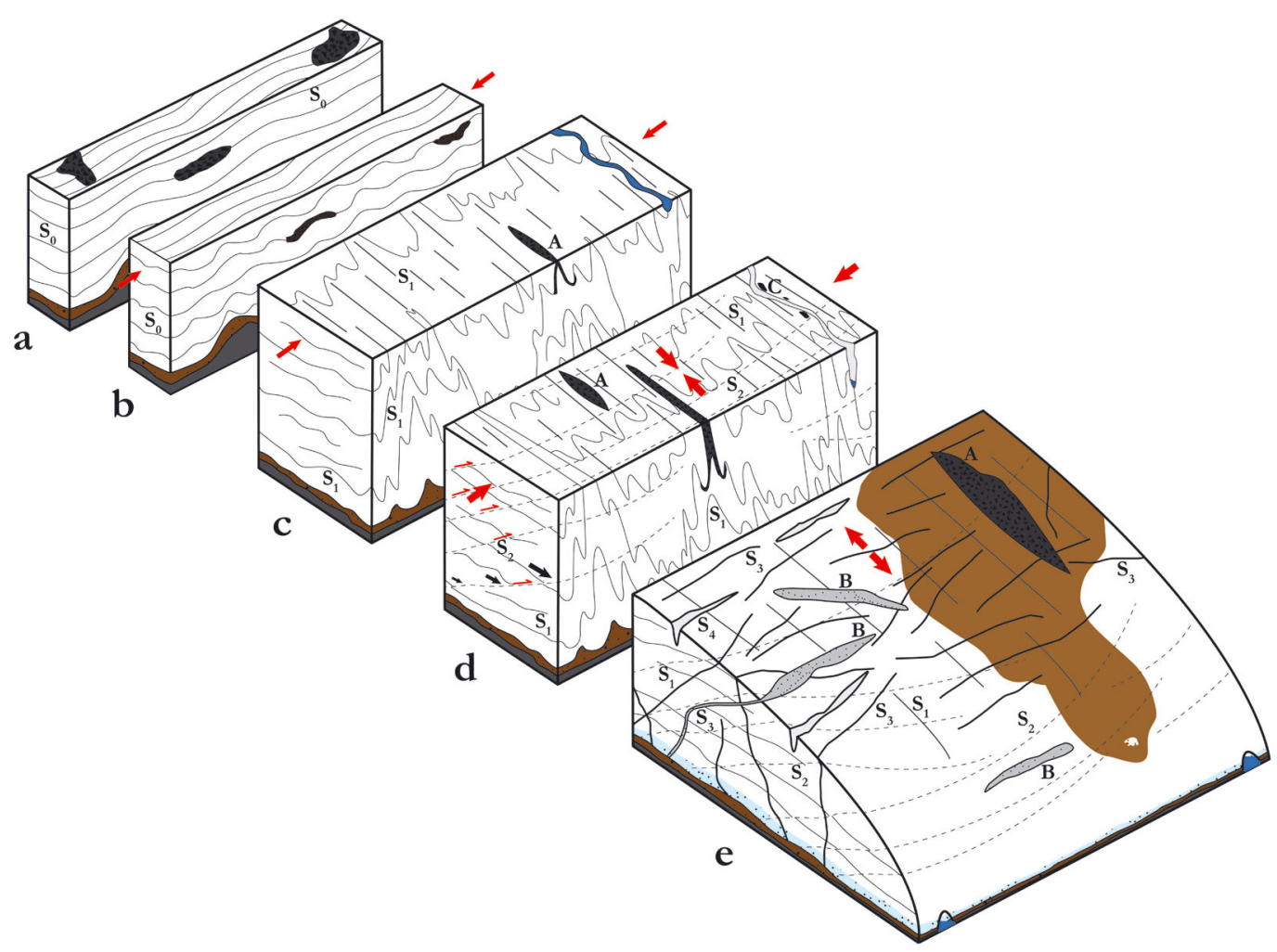

Fig. 10. Schematic diagram of structural formation of Tellbreen and associated geomorphology. $A=$ longitudinal ridge, $B=$ transverse ridge, $\mathrm{C}=$ sand/gravel piles. Parts of this figure are adapted from Hambrey and Glasser (2003).

Hubbard, 2010) or (2) some $S_{3}$ crevasse traces (although not those exposed in the ice caves) are inherited from an earlier phase of extensional flow, pre-dating $S_{2}$ formation.

It seems very unlikely that shear planes are still active within Tellbreen given its current cold-based and nearstagnant flow conditions and the high compressive/transpressive stresses which are necessary to form them. The presence of $S_{2}$ therefore provides compelling evidence that the glacier has been much more dynamic and subjected to high strain rates in the past (cf. Hambrey and others, 2005; Bælum and Benn, 2011). The formation of shear planes in polythermal glaciers is often suggested to occur at the thermal transition between active warm-based ice and inactive cold-based ice at the margin (Rippin and others, 2003; King and others, 2008), where compressive stresses might be expected to be highest. However, the validity of this was questioned by Moore and others (2010, 2011), who found no evidence for a sharp slip/no-slip boundary at the thermal transition within Storglaciären, Sweden, and suggested that longitudinal compression at this boundary may be insufficient to generate compressive fractures. Moore and others (2010) proposed that the required conditions for compressive fracturing are likely to be met only by thin (but actively flowing) glaciers subjected to high compressive stresses and with an abundance of pre-existing weaknesses, which characterizes a surge-type glacier in its active phase. The necessary high compressive stresses would be generated at the transition between areas of extremely weak bed, facilitated by high subglacial water pressures and where ice is temperate and actively surging, and inactive, cold, nonsurging ice towards the glacier margin. The presence of siltsized debris consistent with thin films of waterborne sediment within shear planes supports the suggestion that their development requires hydraulic communication with highly pressurized water (Moore and others, 2010). This provides further evidence that they formed at a time when Tellbreen was experiencing dynamic, warm-based ice flow and elevated subglacial water pressures, in stark contrast to the conditions at the bed of the current cold-based and largely inactive glacier.

\section{Extensional crevassing}

The prevalence of $S_{3}$ fracture traces, interpreted as healed crevasses, within the lower tongue of Tellbreen indicates that the glacier has also experienced significant longitudinal extensional stresses, and the relationship between $S_{2}$ shear planes and $\mathrm{S}_{3}$ crevasse traces observed in the caves (and outlined above) shows that the main phase of extensional flow post-dates the formation of these shear planes (Fig. 10d). The dense population of crevasse traces on the lower tongue suggests that the glacier has been heavily crevassed, since when the crevasses have closed and been transported passively down-glacier as fracture traces (e.g. Hambrey and others, 2005). Extensional crevasses are clearly not forming within the currently cold-based and inactive glacier, and therefore the crevasse traces must have originally formed as open crevasses at a time when the glacier was experiencing far more dynamic ice flow, resulting in significant longitudinal stretching of the ice. Such conditions are consistent with enhanced velocities associated with warm-based ice flow within a thicker glacier at its LIA maximum (Hambrey and others, 2005).

The relationship between $S_{2}$ and $S_{3}$ structures indicates that the ice underwent compressive flow followed by extension, consistent with the down-glacier passage of a surge front or kinematic wave (cf. Lawson and others, 2000). The presence of waterborne sediments within crevasse traces, ranging from well-sorted silt-sized material up to 
sand and gravel, also indicates that the crevasse network was exploited by highly pressurized water, possibly sourced from the temperate bed (Fig. 10e; Evans and Rea, 1999; Ensminger and others, 2001); these crevasse infills can subsequently melt out on the glacier surface (Fig. 9h). Although there are open fractures $\left(\mathrm{S}_{4}\right)$ within Tellbreen (Fig. 8), these are either related to localized collapse due to margin undercutting by meltwater action, or bergschrund-type crevassing on steep slopes in the accumulation area (Bælum and Benn, 2011), and so do not reflect current flow dynamics.

\section{LIA thermal switches and changes to glacier dynamics}

The basal ice and till facies and structural evidence at Tellbreen provides a clear indication that this currently thin and cold-based glacier was much more dynamic in the past. Although direct dating evidence is unavailable, it is most likely that warm-based dynamic flow occurred at the Neoglacial maximum of the glacier, towards the end of the LIA, when Tellbreen was more extensive, contained $\sim 60-70 \%$ more volume and may have been up to $200 \mathrm{~m}$ thick (Bælum and Benn, 2011). The LIA represents the culmination of Neoglacial glacier expansion, which also typically records the most extensive position reached by glaciers during the Holocene (Humlum and others, 2005). Prior to this, conditions during the early and mid-Holocene are suggested to have been warmer than the present-day climate (Salvigsen and others, 1992; Salvigsen, 2002), and most current valley glaciers are likely to have been considerably smaller (Svendsen and Mangerud, 1997; Forwick and Vorren, 2007; Mangerud and Landvik, 2007) or even non-existent (Ingólfsson, 2011) at this time. In the latter case, valley glacier build-up during the early part of the LIA would have been characterized by snow accumulation on permafrost initially leading to the development of cold-based ice; these conditions have persisted beneath some Svalbard glaciers throughout the LIA, as evidenced by the preservation of in situ plants in a subglacial position at Longyearbreen (Humlum and others, 2005). Thickening and steepening associated with glacier growth would have insulated the ice/bed interface and encouraged strain heating of ice in the basal zone (Blatter and Hutter, 1991), creating areas at the pressure-melting-point, which in turn would lead to the generation of meltwater at the bed, facilitating related increases in dynamism in the form of sliding/subglacial deformation and higher ice velocities (Blatter and Hutter, 1991; Hambrey and others, 2005; Bælum and Benn, 2011). This build-up of mass and associated conditions at the bed is likely to have allowed Tellbreen to advance to its LIA maximum position, delimited by latero-frontal ice-cored moraines (Fig. 1b). The build-up effectively records a switch from cold-based to warm-based conditions during the LIA. Saturation and deformation of the subglacial till and strain-induced metamorphism of englacial ice close to the bed occurred as a result of this switch, in the latter case leading to the formation of the dispersed ice facies. The period of enhanced flow velocities and warm-based conditions also facilitated the formation of shear planes $\left(\mathrm{S}_{2}\right)$ and extensional crevasses (precursor to $\mathrm{S}_{3}$ ). Following the LIA, the step-like increase in warming at the start of the 20th century (Hanssen-Bauer and others, 1990) initiated consistently negative mass balances, extensive thinning, and retreat of the lower tongue, instigating a thermal transition from a glacier with areas of warm-based ice back to one which is almost entirely frozen to its bed and in a state of low glacier activity. The saturated subglacial traction till froze to the bed as the thermal regime switched back to cold-based, and the extensional crevasses closed up to form crevasse traces $\left(S_{3}\right)$.

In simple terms, this represents a switch from a warmbased glacier in a cold period (e.g. LIA) to a cold-based glacier in a warmer period (e.g. today). Similar inferences have been made for a handful of small valley glaciers on Svalbard, either where the switch to an entirely cold-based regime is thought to be complete (e.g. Hodgkins and others, 1999; Stuart and others, 2003; Lukas and others, 2005) or is ongoing (e.g. Hambrey and others, 2005). These examples could be part of a broader trend exhibited by small High Arctic valley glaciers of a post-LIA shift from polythermal to cold-based conditions in a warming climate, which is also likely to have wider implications, such as for hydrogeological systems in Arctic regions (e.g. reduction in groundwater recharge; Haldorsen and Heim, 1999; Haldorsen and others, 2010; Scheidegger and others, 2012).

This suggested sequence of thermal switches experienced by Tellbreen from the beginning of the LIA to the present day shares many similarities with the model proposed by Fowler and others (2001) to explain surging of polythermal glaciers. According to that model, build-up of mass in the accumulation area of a largely cold-based glacier at the beginning of its surge cycle results in parts of the bed being raised to the pressure-melting point. This switch to warm-based conditions leads to the production of meltwater and increases subglacial water pressures and pore-water pressures in underlying sediments, resulting in a dramatic shift in glacier dynamics, associated positive feedbacks, and typically glacier advance during the active phase of the surge. Postsurge, the over-extended glacier thins rapidly and begins to freeze to its bed, eventually switching back to largely coldbased conditions. The similarities in the thermal changes and associated flow dynamics experienced by polythermal surge-type glaciers and LIA advances of small valley glaciers on Svalbard have led to some discussion as to whether the latter describe surges or simply 'normal' polythermal glacier behaviour. An example of this is the case of Midtre Lovénbreen, which has been classified as both surge-type (Liestøl, 1988; Hansen, 2003) and non-surge-type (Hambrey and others, 2005), and similar discussions have evolved in relation to Austre Lovénbreen (Jiskoot and others, 2000; Midgley and others, 2013) and Marthabreen (Hagen and others, 1993; Glasser and others, 1999). This difference of opinion, however, is largely semantic. The key point is that a major change in glacier dynamics, controlled by changes to the thermal structure of the glacier, occurs during climate cycles in both cases. Some glaciers (e.g. Tellbreen) appear to have experienced a single dynamic cycle during the LIA, whereas other (typically larger) glaciers have undergone several dynamic cycles, in the form of surges. This suggests an underlying dynamical similarity, expressed in different ways by different glaciers.

\section{CONCLUSIONS}

Evidence for former flow dynamics and changes to the thermal regime of Tellbreen, a cold-based, land-terminating valley glacier in central Spitsbergen, are recorded by glaciological structures and within its basal ice sequence. In common with many other small valley glaciers on Svalbard, Tellbreen has retreated steadily since its LIA 
maximum position, significantly reducing the volume and areal extent of the glacier (Bælum and Benn, 2011). The following conclusions are based on a combination of investigations within meltwater conduits at the glacier front and structural mapping of the surface from aerial photographs.

The basal sequence consists of a frozen matrix-supported diamict overlain by debris-poor dispersed facies ice. The matrix-supported diamict is interpreted as a frozen subglacial traction till which has been highly saturated. The overlying dispersed facies has a tectonic origin, relating to strain-induced metamorphism of englacial ice due to shearing close to the bed. The formation of both facies is consistent with a warm-based thermal regime and the availability of subglacial meltwater.

The sequential development of structures within Tellbreen has been determined, and consists of: (1) the formation of primary stratification through firnification processes in the accumulation area; (2) the folding of primary stratification leading to the development of longitudinal foliation; (3) the formation of arcuate shear planes in the lower glacier tongue in response to compressional and, at the lateral margins, transpressional stress regimes; and (4) the opening of extensional fractures and crevasses and the injection of pressurized meltwater into these, followed by the healing of fractures. Of these, (3) and (4) are strongly indicative of former dynamic, warm-based flow (while none is inconsistent with it).

Both the basal sequence and glaciological structures are consistent with Tellbreen having experienced more-dynamic ice flow in the past, characterized by warm-based conditions, tectonic deformation and the availability of pressurized subglacial meltwater. It is likely that these conditions coincided with the LIA maximum extent of Tellbreen, when it was significantly larger and thicker than today.

This evidence records switches in the thermal regime of Tellbreen, from a small early-LIA cold-based glacier to a polythermal glacier with extensive areas of warm-based ice at the LIA maximum, before returning to a glacier which is almost entirely frozen to its bed post-LIA. This sequence is similar to the thermal switch proposed for polythermal surge-type glaciers, suggesting an underlying dynamical similarity. It is likely that many more small valley glaciers in Svalbard have also experienced, or are currently undergoing, a similar switch in response to climatic warming and consistently negative mass balances since their LIA maxima.

\section{ACKNOWLEDGEMENTS}

H.L. was funded by a UK Natural Environment Research Council (NERC) PhD studentship (NE/I528050/1), the Queen Mary Postgraduate Research Fund, and an Arctic Field Grant from the Research Council of Norway. E.J.F. was funded by a NERC PhD studentship as part of the GAINS (Glacial Activity in Neoproterozoic Svalbard) grant (NE/ H004963/1). K.N. was funded by an Arctic Field Grant, the Swiss Society for Speleology, and the travel grant commission of the Swiss Academy of Science. Landsat satellite images were provided by US Geological Survey (USGS) Earth Explorer, and aerial photographs were acquired from Norsk Polarinstitutt. We thank lan Boomer for isotope analyses, UNIS logistics (particularly Martin Indreiten, Jukka Pekka Ikonen and Monika Votvik) and Philipp Schuppli for fieldwork support, and all members of the UNIS AG-325 Glaciology course who were present when we first visited
Tellbreen in 2011. Andy Hodson provided helpful advice on various aspects of the work. The paper also benefited significantly from thorough and constructive reviews by Dave Evans and Richard Waller. We thank the International Glaciological Society for support with the publication of this paper.

\section{REFERENCES}

Alley RB, Cuffey KM, Evenson EB, Strasser JC, Lawson DE and Larson GJ (1997) How glaciers entrain and transport basal sediment: physical constraints. Quat. Sci. Rev., 16(9), 1017-1038 (doi: 10.1016/S0277-3791(97)00034-6)

Bælum K and Benn DI (2011) Thermal structure and drainage system of a small valley glacier (Tellbreen, Svalbard), investigated by ground penetrating radar. Cryosphere, 5(1), 139-149 (doi: 10.5194/tc-5-139-2011)

Benn DI (2004) Macrofabric. In Evans DJA and Benn DI eds. A practical guide to the study of glacial sediments. Hodder Arnold, Abingdon, 93-114

Benn DI and Evans DJA (2010) Glaciers and glaciation, 2nd edn. Hodder Education, London

Bennett MR, Huddart D and Waller RI (2000) Glaciofluvial crevasse and conduit fills as indicators of supraglacial dewatering during a surge, Skeiðarárjökull, Iceland. J. Glaciol., 46(152), 25-34 (doi: 10.3189/172756500781833232)

Bjørnsson $\mathrm{H}$ and 6 others (1996) The thermal regime of sub-polar glaciers mapped by multi-frequency radio-echo sounding. J. Glaciol., 42(140), 23-32

Blatter H and Hutter K (1991) Polythermal conditions in Arctic glaciers. J. Glaciol., 37(126), 261-269

Blott SJ and Pye K (2001) GRADISTAT: a grain size distribution and statistics package for the analysis of unconsolidated sediments. Earth Surf. Process. Landf., 26(11), 1237-1248 (doi: 10.1002/ esp.261)

Christoffersen P and Tulaczyk S (2003) Response of subglacial sediments to basal freeze-on: I. Theory and comparison to observations from beneath the West Antarctic ice sheet. J. Geophys. Res., 108(B4), 2222 (doi: 10.1029/2002JB001935)

Christoffersen P, Tulaczyk S, Carsey FD and Behar AE (2006) A quantitative framework for interpretation of basal ice facies formed by ice accretion over subglacial sediment. J. Geophys. Res., 111(F1), F01017 (doi: 10.1029/2005JF000363)

Cook SJ, Robinson ZP, Fairchild IJ, Knight PG, Waller RI and Boomer I (2010) Role of glaciohydraulic supercooling in the formation of stratified facies basal ice: Svínafellsjökull and Skaftafellsjökull, southeast Iceland. Boreas, 39(1), 24-38 (doi: 10.1111/j.1502-3885.2009.00112.x)

Cook SJ, Swift DA, Graham DJ and Midgley NG (2011) Origin and significance of 'dispersed facies' basal ice: Svínafellsjökull, Iceland. J. Glaciol., 57(204), 710-720 (doi: 10.3189/ 002214311797409703)

Dallmann W, Ohta Y, Elvevold S and Blomeier D (2002) Bedrock map of Svalbard and Jan Mayen. 1:750,000 with enlarged areas 1:250,000. Theme Map No. 33. Norwegian Polar Institute, Tromse

Divine DV and 8 others (2008) Deuterium excess record from a small Arctic ice cap. J. Geophys. Res., 113(D19), D19104 (doi: 10.1029/2008JD010076)

Dowdeswell JA and 10 others (1997) The mass balance of circumArctic glaciers and recent climate change. Quat. Res., 48(1), 1-14

Ensminger SL, Alley RB, Evenson EB, Lawson DE and Larson GJ (2001) Basal-crevasse-fill origin of laminated debris bands at Matanuska Glacier, Alaska, U.S.A. J. Glaciol., 47(158), 412-422 (doi: 10.3189/172756501781832007)

Etzelmüller B, Hagen JO, Vatne G, Ødegård RS and Sollid JL (1996) Glacier debris accumulation and sediment deformation influenced by permafrost: examples from Svalbard. Ann. Glaciol., 22, 53-62 
Evans DJA (1989) Apron entrainment at the margins of sub-polar glaciers, north-west Ellesmere Island, Canadian High Arctic. J. Glaciol., 35(121), 317-324

Evans DJA (2009) Controlled moraines: origins, characteristics and palaeoglaciological implications. Quat. Sci. Rev., 28(3-4), 183208 (doi: 10.1016/j.quascirev.2008.10.024)

Evans DJA and Benn DI (2004) Facies description and the logging of sedimentary exposures. In Evans DJA and Benn DI eds. A practical guide to the study of glacial sediments. Hodder Arnold, London, 11-50

Evans DJA and Rea BR (1999) Geomorphology and sedimentology of surging glaciers: a land-systems approach. Ann. Glaciol., 28, 75-82 (doi: 10.3189/172756499781821823)

Evans DJA, Phillips ER, Hiemstra JF and Auton CA (2006) Subglacial till: formation, sedimentary characteristics and classification. Earth-Sci. Rev., 78(1-2), 115-176 (doi: 10.1016/ j.earscirev.2006.04.001)

Eyles N and Rogerson RJ (1978) Sedimentology of medial moraines on Berendon Glacier, British Columbia, Canada: implications for debris transport in a glacierized basin. Geol. Soc. Am. Bull., 89(11), 1688-1693

Fleming EJ and 6 others (2013) Magnetic fabrics in the basal ice of a surge-type glacier. J. Geophys. Res., 118(4), 2263-2278 (doi: 10.1002/jgrf.20144)

Forwick M and Vorren TO (2007) Holocene mass-transport activity and climate in outer Isfjorden, Spitsbergen: marine and subsurface evidence. Holocene, 17(6), 707-716 (doi: 10.1177/ 0959683607080510)

Forwick M and Vorren TO (2009) Late Weichselian and Holocene sedimentary environments and ice rafting in Isfjorden, Spitsbergen. Palaeogeogr., Palaeoclimatol., Palaeoecol., 280(1-2), 258-274 (doi: 10.1016/j.palaeo.2009.06.026)

Fowler AC (1984) On the transport of moisture in polythermal glaciers. Geophys. Astrophys. Fluid Dyn., 28(2), 99-140

Fowler AC, Murray T and Ng FSL (2001) Thermally controlled glacier surging. J. Glaciol., 47(159), 527-538 (doi: 10.3189/ 172756501781831792)

Glasser NF, Bennett MR and Huddart D (1999) Distribution of glaciofluvial sediment within and on the surface of a high Arctic valley glacier: Marthabreen, Svalbard. Earth Surf. Process. Landf., 24(4), 303-318 (doi: 10.1002/(SICI)1096-9837(199904) 24:4<303::AID-ESP952>3.0.CO;2-8)

Glasser NF, Hambrey MJ, Etienne JL, Jansson P and Pettersson R (2003) The origin and significance of debris-charged ridges at the surface of Storglaciären, northern Sweden. Geogr. Ann., Ser. A, 85(2), 127-147 (doi: 10.1111/1468-0459.00194)

Graham DJ and Midgley NG (2000) Graphical representation of particle shape using triangular diagrams: an Excel spreadsheet method. Earth Surf. Process. Landf., 25(13), 1473-1477 (doi: 10.1002/1096-9837(200012)25:13<1473::AID-ESP158>3.0. $\mathrm{CO} ; 2-\mathrm{C})$

Hagen JO, Liestøl O, Roland E and Jørgensen T (1993) Glacier atlas of Svalbard and Jan Mayen. Nor. Polarinst. Medd. 129

Haldorsen S and Heim M (1999) An Arctic groundwater system and its dependence upon climatic change: an example from Svalbard. Permafrost Periglac. Process., 10(2), 137-149

Haldorsen S and 8 others (2010) Sensitivity to long-term climate change of subpermafrost groundwater systems in Svalbard. Quat. Res., 73(2), 393-402 (doi: 10.1016/ j.yqres.2009.11.002)

Hambrey MJ (1975) The origin of foliation in glaciers: evidence from some Norwegian examples. J. Glaciol., 14(70), 181-185

Hambrey MJ (1976) Structure of the glacier Charles Rabots Bre, Norway. Geol. Soc. Am. Bull., 87(11), 1629-1637

Hambrey MJ and Dowdeswell JA (1997) Structural evolution of a surge-type polythermal glacier: Hessbreen, Svalbard. Ann. Glaciol., 24, 375-381

Hambrey MJ and Glasser NF (2003) The role of folding and foliation development in the genesis of medial moraines: examples from Svalbard glaciers. J. Geol., 111(4), 471-485
Hambrey MJ and Müller F (1978) Structures and ice deformation in the White Glacier, Axel Heiberg Island, Northwest Territories, Canada. J. Glaciol., 20(82), 41-66

Hambrey MJ and 7 others (2005) Structure and changing dynamics of a polythermal valley glacier on a centennial timescale: Midre Lovénbreen, Svalbard. J. Geophys. Res., 110(F1), F01006 (doi: 10.1029/2004JF000128)

Hansen S (2003) From surge-type to non-surge-type glacier behaviour: midre Lovénbreen, Svalbard. Ann. Glaciol., 36, 97-102 (doi: 10.3189/172756403781816383)

Hanssen-Bauer I, Solås MK and Steffensen EL (1990) The climate of Spitsbergen. (DNMI-Rapp. KLIMA 39-90) Norsk Meteorologisk Institutt, Oslo

Hodgkins R, Hagen JO and Hamran SE (1999) 20th century mass balance and thermal regime change at Scott Turnerbreen, Svalbard. Ann. Glaciol., 28, 216-220 (doi: 10.3189/ 172756499781821986)

Hodson A and 7 others (2008) Glacial ecosystems. Ecol. Monogr., 78(1), 41-67 (doi: 10.1890/07-0187.1)

Hoey TB (2004) The size of sedimentary particles. In Evans DJA and Benn DI eds. A practical guide to the study of glacial sediments. Hodder Arnold, Abingdon, 52-77

Hubbard B and Sharp M (1993) Weertman regelation, multiple refreezing events and the isotopic evolution of the basal ice layer. J. Glaciol., 39(132), 275-291

Hubbard B and Sharp M (1995) Basal ice facies and their formation in the western Alps. Arct. Alp. Res., 27(4), 301-310

Hubbard B, Tison JL, Janssens L and Spiro B (2000) Ice-core evidence of the thickness and character of clear-facies basal ice: Glacier de Tsanfleuron, Switzerland. J. Glaciol., 46(152), 140-150 (doi: 10.3189/172756500781833250)

Hubbard B, Cook S and Coulson H (2009) Basal ice facies: a review and unifying approach. Quat. Sci. Rev., 28(19-20), 1956-1969 (doi: 10.1016/j.quascirev.2009.03.005)

Humlum O, Elberling B, Hormes A, Fjordheim $\mathrm{K}$, Hansen $\mathrm{OH}$ and Heinemeier J (2005) Late-Holocene glacier growth in Svalbard, documented by subglacial relict vegetation and living soil microbes. Holocene, 15(3), 396-407 (doi: 10.1191/ 0959683605hl817rp)

Ingólfsson Ó (2011) Fingerprints of Quaternary glaciations on Svalbard. In Martini IP, French HM and Perez-Alberti A eds Icemarginal and periglacial processes and sediments. (Special Publication SP354) Geological Society, Bath, 15-31

Iverson NR and Souchez R (1996) Isotopic signature of debris-rich ice formed by regelation into a subglacial sediment bed. Geophys. Res. Lett., 23(10), 1151-1154

Jiskoot H, Murray T and Boyle P (2000) Controls on the distribution of surge-type glaciers in Svalbard. J. Glaciol., 46(154), 412-422 (doi: 10.3189/172756500781833115)

Kamb B and LaChapelle E (1964) Direct observation of the mechanism of glacier sliding over bedrock. J. Glaciol., 5(38), 159-172

King EC, Smith AM, Murray T and Stuart GW (2008) Glacier-bed characteristics of midtre Lovénbreen, Svalbard, from highresolution seismic and radar surveying. J. Glaciol., 54(184), 145-156 (doi: 10.3189/002214308784409099)

Knight PG (1987) Observations at the edge of the Greenland ice sheet: boundary condition implications for modellers. IAHS Publ. 170 (Symposium at Vancouver 1987 - The Physical Basis of Ice Sheet Modelling), 359-366

Knight PG (1997) The basal ice layer of glaciers and ice sheets. Quat. Sci. Rev., 16(9), 975-993 (doi: 10.1016/S0277-3791(97) 00033-4)

Knight PG and Knight DA (1994) Correspondence. Glacier sliding, regelation water flow and development of basal ice. J. Glaciol., 40(136), 600-601

Larsen NK, Kronborg C, Yde JC and Knudsen NT (2010) Debris entrainment by basal freeze-on and thrusting during the 19951998 surge of Kuannersuit Glacier on Disko Island, west Greenland. Earth Surf. Process. Landf., 35(5), 561-574 (doi: 10.1002/esp.1945) 
Lawson DE (1979) Sedimentological analysis of the western terminus region of the Matanuska Glacier, Alaska. CRREL Rep. 79-9

Lawson WJ, Sharp MJ and Hambrey MJ (2000) Deformation histories and structural assemblages of glacier ice in a nonsteady flow regime. In Maltman AJ, Hubbard B and Hambrey MJ eds Deformation of glacial materials. (Special Publication 176) Geological Society, London, 85-96

Liestøl O (1988) The glaciers in the Kongsfjorden area, Spitsbergen. Nor. Geogr. Tidsskr., 42(4), 231-238

Lliboutry L (1993) Internal melting and ice accretion at the bottom of temperate glaciers. J. Glaciol., 39(131), 50-64

Lukas S, Nicholson LI, Ross FH and Humlum O (2005) Formation, meltout processes and landscape alteration of high-Arctic icecored moraines: examples from Nordenskild Land, Central Spitsbergen. Polar Geogr., 29(3), 157-187 (doi: 10.1080/ 789610198)

Lukas S and 16 others (2013) Clast shape analysis and clast transport paths in glacial environments: a critical review of methods and the role of lithology. Earth-Sci. Rev., 121, 96-116

Mangerud J and Landvik JY (2007) Younger Dryas cirque glaciers in western Spitsbergen: smaller than during the Little Ice Age. Boreas, 36(3), 278-285 (doi: 10.1111/j.1502-3885.2007. tb01250.x)

Midgley NG, Tonkin TN, Cook SJ and Graham DJ (2013) Origin, evolution and dynamic context of a Neoglacial lateral-frontal moraine at Austre Lovénbreen, Svalbard. Geomorphology, 198, 96-106 (doi: 10.1016/j.geomorph.2013.05.017)

Moore PL, Iverson NR and Cohen D (2010) Conditions for thrust faulting in a glacier. J. Geophys. Res., 115(F2), F02005 (doi: 10.1029/2009JF001307)

Moore PL, Iverson NR, Brugger KA, Cohen D, Hooyer TS and Jansson $P$ (2011) Effect of a cold margin on ice flow at the terminus of Storglaciären, Sweden: implications for sediment transport. J. Glaciol., 57(201), 77-87 (doi: 10.3189/002214311795306583)

Naegeli K, Lovell H, Zemp M and Benn DI (2014) Dendritic subglacial drainage systems in cold glaciers formed by cut-andclosure processes. Geogr. Ann., Ser. A, 96(4), 591-608 (doi: 10.1111/geoa.12059)

Nye JF (1952) The mechanics of glacier flow. J. Glaciol., 2(12), 82-93

Rea BR and Evans DJA (2011) An assessment of surge-induced crevassing and the formation of crevasse squeeze ridges. J. Geophys. Res., 116(F4), F04005 (doi: 10.1029/2011JF001970)

Rees WG and Arnold NS (2007) Mass balance and dynamics of a valley glacier measured by high-resolution LiDAR. Polar Rec., 43(4), 311-319 (doi: 10.1017/S0032247407006419)

Rippin D and 6 others (2003) Changes in geometry and subglacial drainage of Midre Lovénbreen, Svalbard, determined from digital elevation models. Earth Surf. Process. Landf., 28(3), 273-298 (doi: 10.1002/esp.485)

Roberson S (2008) Structural composition and sediment transfer in a composite cirque glacier: Glacier de St. Sorlin, France. Earth Surf. Process. Landf., 33(13), 1931-2120 (doi: 10.1002/esp.1635)
Roberson S and Hubbard B (2010) Application of borehole optical televiewing to investigating the 3-D structure of glaciers: implications for the formation of longitudinal debris ridges, midre Lovénbreen, Svalbard. J. Glaciol., 56(195), 143-156 (doi: 10.3189/002214310791190802)

Roberts DH, Yde JC, Knudsen NT, Long AJ and Lloyd JM (2009) Ice marginal dynamics during surge activity, Kuannersuit Glacier, Disko Island, West Greenland. Quat. Sci. Rev., 28(3-4), 209-222 (doi: 10.1016/j.quascirev.2008.10.022)

Röller, K and Trepmann, CA (2008) Stereo32, version 1.0.1. Institut für Geologie, Mineralogie und Geophysik, Ruhr-Universität Bochum, Bochum

Salvigsen O (2002) Radiocarbon-dated Mytilus edulis and Modiolus modiolus from northern Svalbard: climatic implications. Nor. Geogr. Tidsskr., 56(2), 56-61

Salvigsen O, Forman SL and Miller GH (1992) Thermophilous molluscs on Svalbard during the Holocene and their paleoclimatic implications. Polar Res., 11(1), 1-10 (doi: 10.1111/ j.1751-8369.1992.tb00407.x)

Scheidegger JM, Bense VF and Grasby SE (2012) Transient nature of Arctic spring systems driven by subglacial meltwater. Geophys. Res. Lett., 39(12), L12405 (doi: 10.1029/2012GL051445)

Sharp M, Jouzel J, Hubbard B and Lawson W (1994) The character, structure and origin of the basal ice layer of a surge-type glacier. J. Glaciol., 40(135), 327-340

Souchez RA (1967) The formation of shear moraines: an example from south Victoria Land, Antarctica. J. Glaciol., 6(48), 837-843

Souchez RA and Jouzel J (1984) On the isotopic composition in $\delta D$ and $\delta^{18} \mathrm{O}$ of water and ice during freezing. J. Glaciol., 30(106), 369-372

Souchez R, Lorrain R, Tison JL and Jouzel J (1988) Co-isotopic signature of two mechanisms of basal-ice formation in Arctic outlet glaciers. Ann. Glaciol., 10, 163-166

Stuart G, Murray T, Gamble N, Hayes K and Hodson A (2003) Characterization of englacial channels by ground-penetrating radar: an example from Austre Brøggerbreen, Svalbard. J. Geophys. Res., 108(B11), 2525 (doi: 10.1029/2003JB002435)

Sugden DE, Clapperton CM, Gemmell JC and Knight PG (1987) Stable isotopes and debris in basal glacier ice, South Georgia, Southern Ocean. J. Glaciol., 33(115), 324-329

Svendsen JI and Mangerud J (1997) Holocene glacial and climatic variations on Spitsbergen. Holocene, 7(1), 45-57

Tranter M, Skidmore M and Wadham J (2005) Hydrological controls on microbial communities in subglacial environments. Hydrol. Process., 19(4), 995-998 (doi: 10.1002/hyp.5854)

Twiss RJ and Moores EM (2007) Structural geology. WH Freeman, New York,

Waller RI (1997) The role of tectonism in the distribution, appearance and dynamic behaviour of debris-rich basal ice. (PhD thesis, University of Southampton)

Waller RI, Hart JK and Knight PG (2000) The influence of tectonic deformation on facies variability in stratified debris-rich basal ice. Quat. Sci. Rev., 19(8), 775-786 (doi: 10.1016/S0277-3791 (99)00035-9) 